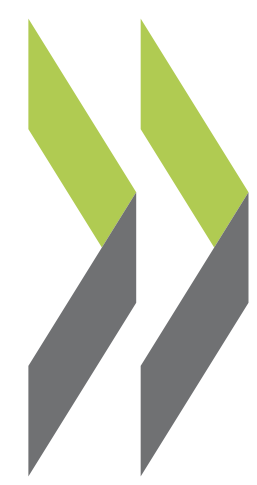

OECD Economics Department Working Papers No. 1492 Stabilisation policies to strengthen Euro area resilience

\section{Jan Stráský,}

\section{Guillaume Claveres}




\section{By Jan Stráský and Guillaume Claveres}

OECD Working Papers should not be reported as representing the official views of the OECD or of its member countries. The opinions expressed and arguments employed are those of the author(s).

Authorised for publication by Isabell Koske, Deputy Director, Country Studies Branch, Economics Department.

All Economics Department Working Papers are available at www.oecd.org/eco/workingpapers.

\section{JT03434648}


OECD Working Papers should not be reported as representing the official views of the OECD or of its member countries. The opinions expressed and arguments employed are those of the author(s).

Working Papers describe preliminary results or research in progress by the author(s) and are published to stimulate discussion on a broad range of issues on which the OECD works.

Comments on Working Papers are welcomed, and may be sent to OECD Economics Department, 2 rue André Pascal, 75775 Paris Cedex 16, France, or by e-mail to eco.contact@oecd.org.

All Economics Department Working Papers are available at www.oecd.org/eco/workingpapers.

This document and any map included herein are without prejudice to the status of or sovereignty over any territory, to the delimitation of international frontiers and boundaries and to the name of any territory, city or area.

The statistical data for Israel are supplied by and under the responsibility of the relevant Israeli authorities. The use of such data by the OECD is without prejudice to the status of the Golan Heights, East Jerusalem and Israeli settlements in the West Bank under the terms of international law.

On 3 May 2018, the OECD Council invited Lithuania to become a Member. At the time of preparation the deposit of Lithuania's instrument of accession to the OECD Convention was pending and therefore Lithuania does not appear in the list of OECD Members and is not included in the OECD zone aggregates.

On 25 May 2018, the OECD Council invited Colombia to become a Member. At the time of preparation the deposit of Colombia's instrument of accession to the OECD Convention was pending and therefore Colombia does not appear in the list of OECD Members and is not included in the OECD zone aggregates.

C) OECD (2018)

You can copy, download or print OECD content for your own use, and you can include excerpts from OECD publications, databases and multimedia products in your own documents, presentations, blogs, websites and teaching materials, provided that suitable acknowledgment of OECD as source and copyright owner is given. All requests for commercial use and translation rights should be submitted to rights@oecd.org 


\section{ABSTRACT/RÉSUMÉ \\ Stabilisation policies to strengthen Euro area resilience}

The euro area sovereign debt crisis highlighted important weaknesses in the euro area design. Fiscal policy did not build sufficient buffers before the crisis, which forced some countries to tighten fiscal policy too rapidly during the downturn to restore market confidence in sovereign borrowing. Despite this, sovereign stress remained high, weakening further the banking sectors highly exposed to government bonds, which in return reduced further market confidence in fiscal sustainability in case of banks' bailout. As a result, monetary policy was the main public instrument to support the activity, but its effectiveness was reduced by the fragmentation of financial markets along national lines as the crisis deepened. In order to durably sever the links between banks and their sovereigns, euro area countries agreed on a banking union. The creation of a common supervisor was a very important step in that direction. However, further progress is needed in reducing and sharing risks, creating a common deposit guarantee scheme and the application of existing rules to ensure sufficient risk sharing can take place in case of crisis. At the same time, incentives need to be put in place for banks to progressively move away from a too high exposure to domestic sovereign bonds. A step in that direction could be the introduction of euro area safe asset, which would pool sovereign issuance from various countries, in parallel with gradual introduction of capital surcharges on sovereign exposures. Such progress may not be sufficient, however, for national fiscal policies and monetary policy to smooth a major crisis. The introduction of common fiscal stabilisation capacity is necessary to buttress the euro area in case of a deep recession, both at the country level and euro area level. Finally, policies aiming at further crossborder integration of capital markets should reinforce private risk sharing, reducing the burden on macro policies.

This Working Paper relates to the 2018 OECD Economic Survey of the Euro Area. (http://www.oecd.org/eco/surveys/economic-survey-european-union-and-euro-area.htm) JEL classification: E32, E61, E62, F42, G21, H87

Keywords: risk-sharing, European deposit insurance, sovereign debt exposures of banks, European safe asset, macroeconomic stabilisation, fiscal integration, Capital markets union

\section{Des politiques de stabilisation à même de rendre la Zone Euro plus résiliente}

La crise des dettes souveraines qui a secoué la zone euro a montré que celle-ci souffrait de défauts de conception importants. La politique budgétaire n'est pas parvenue à instaurer des mécanismes régulateurs suffisamment efficaces avant la crise, en conséquence de quoi certains pays ont été contraints de resserrer leur politique budgétaire de façon précipitée pendant la période de ralentissement afin de pouvoir rétablir la confiance des marchés dans les emprunts publics. Malgré cela, les tensions sur les dettes souveraines sont restés élevées, ce qui a affaibli encore davantage les secteurs bancaires fortement exposés aux obligations d'État et fait douter un peu plus les marchés de la viabilité des finances publiques dans l'éventualité d'un sauvetage des banques. Dans ces circonstances, la politique monétaire est devenue le principal instrument de soutien public à l'activité, mais elle a perdu de son efficacité à mesure que les marchés financiers se sont fragmentés selon les frontières nationales sous l'effet de l'enracinement de la crise.

Pour couper durablement les liens entre les banques et leurs emprunteurs souverains, les pays de la zone euro se sont mis d'accord pour établir une union bancaire. La mise en place d'une autorité de surveillance commune a été un pas très important dans cette voie. Il faut cependant poursuivre les efforts sur la voie de la réduction et du partage des risques, en créant un système commun de garantie des dépôts et en appliquant les règles existantes pour assurer un partage des risques suffisant en cas de crise. Parallèlement, des mesures doivent être prises pour inciter les banques à réduire progressivement leur exposition excessive aux obligations souveraines nationales. Une première étape pourrait consister à créer un actif sans risque pour la zone euro, qui réunirait des obligations souveraines de différents pays, et en parallèle, à introduire progressivement des exigences supplémentaires de fonds propres applicables aux expositions souveraines. Ces avancées pourraient néanmoins ne pas suffire si l'on veut que les politiques budgétaires et monétaires nationales soient capables de résorber une crise majeure. Créer une capacité de stabilisation budgétaire commune est nécessaire pour pouvoir soutenir la zone euro en cas de récession profonde, au niveau des pays et au niveau de la zone euro. Enfin, les politiques visant à accentuer l'intégration transfrontalière des marchés des capitaux devraient veiller à renforcer le partage privé des risques pour alléger la charge pesant sur les politiques macroéconomiques.

Ce Document de travail se rapporte à l'Étude économique de l'OCDE de la Zone Euro, 2018

(http://www.oecd.org/fr/eco/etudes/etude-economique-union-europeenne-et-zone-euro.htm)

Classification JEL: E32, E61, E62, F42, G21, H87

Mots clefs: partage des risques, système européen d'assurance des dépôts, exposition des banques aux dettes souveraines, actif européen sûr, stabilisation macroéconomique, intégration fiscale, Union des marchés des capitaux 


\section{Table of contents}

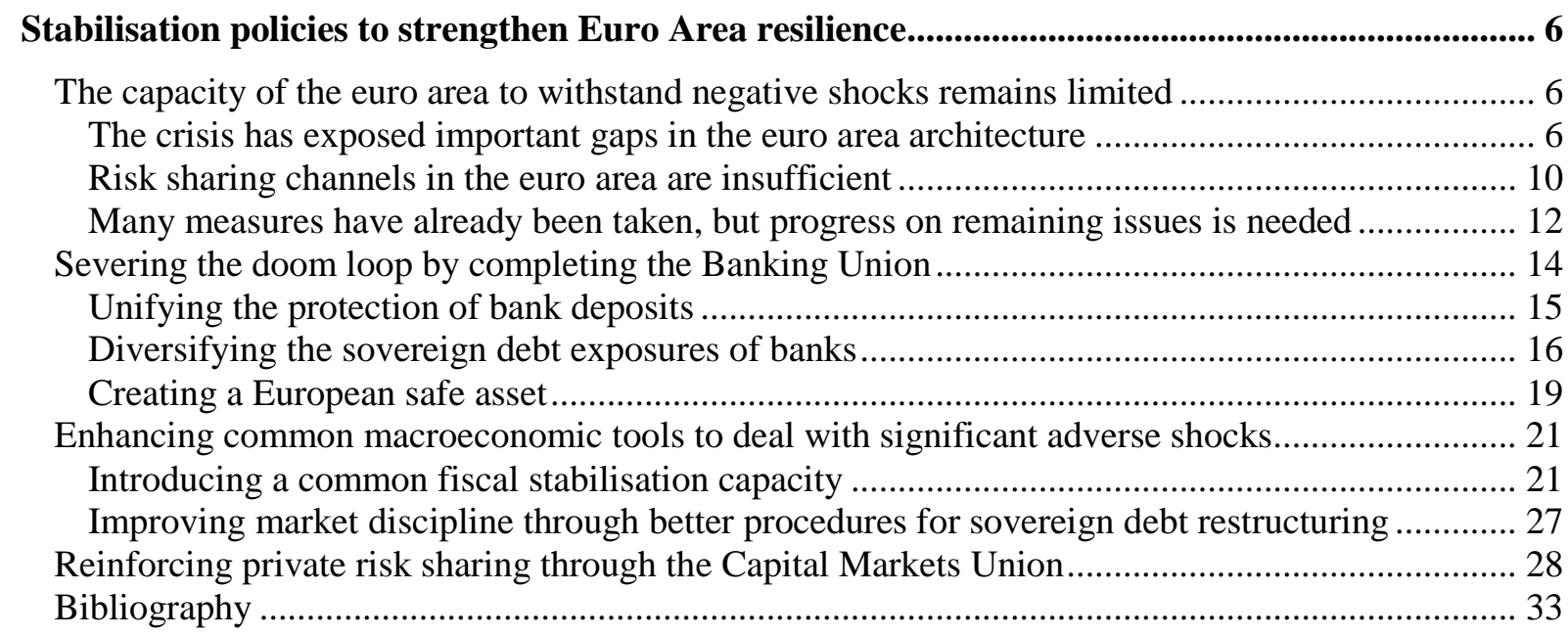

\section{Tables}

Table 1. Overview of the euro area reform instruments.

Table 2. Transfers to and from the unemployment benefit re-insurance scheme.

\section{Figures}

Figure 1. Euro area convergence has reversed since the crisis

Figure 2. The crisis triggered a readjustment in external balance and public debt................................ 7

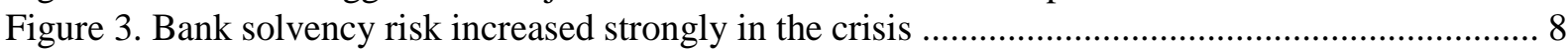

Figure 4 . The potentially harmful link between banks and sovereigns gradually weakened in the aftermath of the financial crisis

Figure 5. After the crisis, fiscal policy was not very supportive ....................................................... 9

Figure 6. Dispersion of economic performance in the euro area is decreasing again ........................... 10

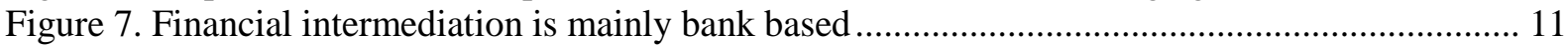

Figure 8. Cross-border positions of euro area monetary financial institutions remain limited ............. 11

Figure 9. 10-year government bond nominal yields in Italy and Spain declined after the ECB action 13

Figure 10. General government securities held by banks are mainly domestic ................................... 17

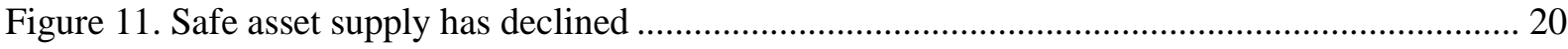

Figure 12. European unemployment fund would reinsure the existing national schemes ................... 23

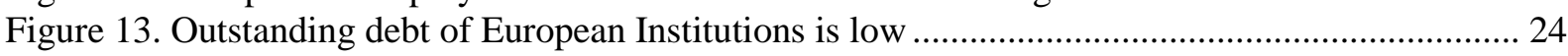

Figure 14. Macroeconomic stabilisation properties of the simulated EURS......................................... 26

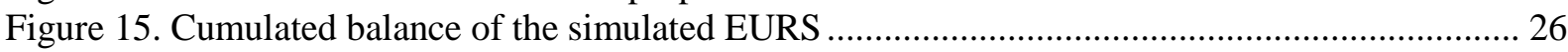

Figure 16. Financial assets held by households are mainly domestic ................................................ 28

Figure 17. Insolvency regimes vary considerably across countries ................................................. 30 


\section{Boxes}

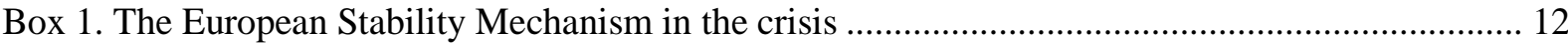

Box 2. Current regulatory treatment of sovereign exposures in the euro area ................................... 17

Box 3. Counterfactual simulations of the euro area unemployment re-insurance scheme for 2000 2016 


\title{
Stabilisation policies to strengthen Euro Area resilience
}

\author{
By Jan Strasky and Guillaume Claveres ${ }^{1}$
}

\section{The capacity of the euro area to withstand negative shocks remains limited}

\section{The crisis has exposed important gaps in the euro area architecture}

In the first years of its existence, the euro seems to have contributed to economic convergence in the euro area. With the benefit of hindsight, it seems possible that at least some of the convergence gains were due to only a moderation of country-specific shocks, alongside the build-up of unsustainable imbalances and mispricing of sovereign risk. As a result, the economic convergence achieved early in the euro's existence has been reversed since the crisis and the recent economic recovery has prevented further deterioration (Figure 1).

Figure 1. Euro area convergence has reversed since the crisis

Euro area real GDP as a fraction of German GDP, PPP-adjusted, per capita, population weighted 100
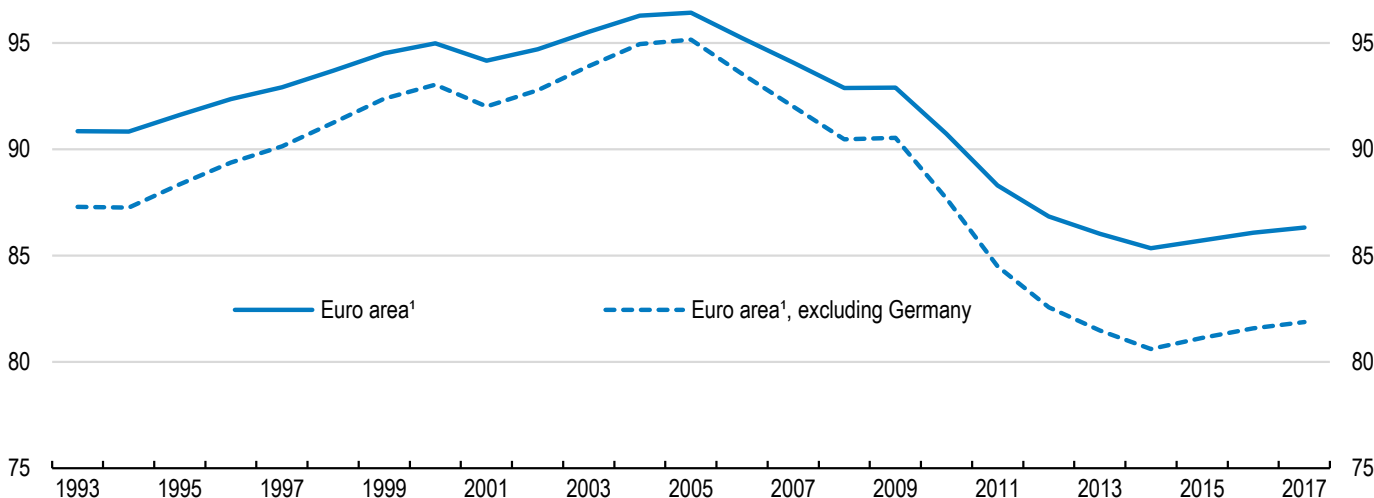

1. Changing composition

Source: The Conference Board (2018), Total Economy Database.

StatLink 제은 http://dx.doi.org/10.1787/888933741599

\footnotetext{
${ }^{1}$ Jan Stráský is Economist at the European Union/Euro Area desk in the Country Studies Branch of the OECD Economics Department (Jan.STRASKY@oecd.org). At the time of writing, Guillaume Claveres was Junior Economist at the European Union/Euro Area desk in the Country Studies Branch of the OECD Economics Department. The authors would like to thank Geoff Barnard, Pierre Beynet, Aida Caldera, Robert Ford, Asa Johansson, Isabell Koske, Alessandro Maravalle, Álvaro Pereira, Lukasz Rawdanowicz and Juan Yermo of the OECD, as well as the European Commission and ECB officials, for their valuable comments and suggestions on the previous versions of the paper. The authors are also grateful to Patrizio Sicari for statistical assistance and Elisabetta Pilati for editorial assistance.
} 
The euro area sovereign debt crisis was characterised by a sudden stop in cross-border lending, as investors adjusted financing flows to banks and governments in many countries, sharply reversing intra-euro area capital flows that gradually built up prior to the crisis. Slowing growth then lead to big budget deficits and rapidly increasing public debt ratios, in particular in countries where governments assumed some of their banks' debt (Figure 2). Moreover, euro area sovereigns facing financing difficulties did not have access to the lender of last resort, as national central banks could not create money to lend to sovereigns and the European Central Bank was explicitly forbidden to do so (Baldwin et al., 2015). Without the stabilising role of the lender of last resort, risk premia on government borrowing increased sharply, reinforcing budget deficits and future borrowing needs.

Figure 2. The crisis triggered a readjustment in external balance and public debt

Euro area ${ }^{1}$

A. Current account balance As a percentage of GDP

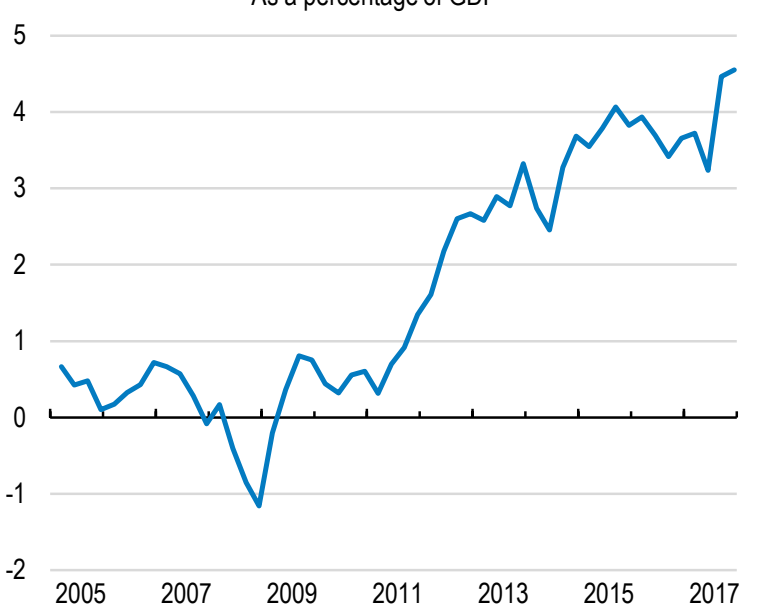

B. Gross public debt Maastricht definition, as a percentage of GDP

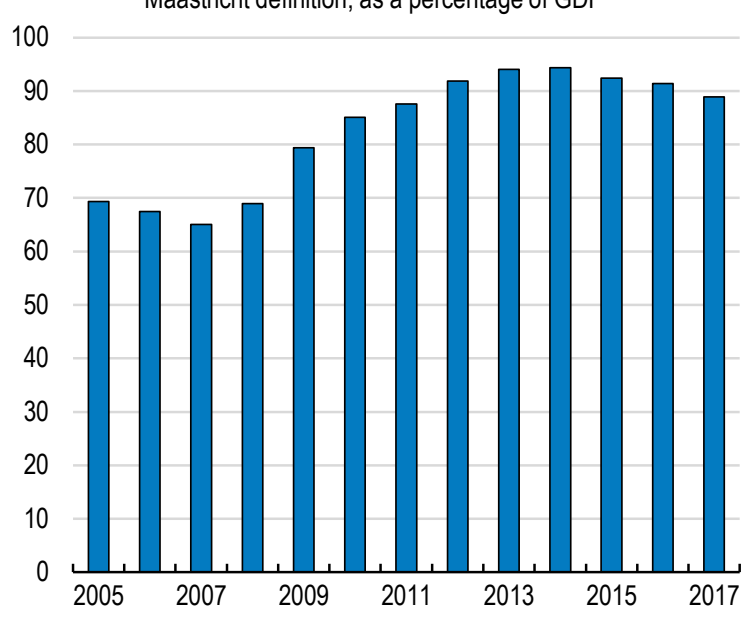

1. Euro area member countries that are also members of the OECD (16 countries). Source: OECD (2018), OECD Economic Outlook: Statistics and Projections (database).

StatLink 제패 http://dx.doi.org/10.1787/888933741618

The close links between banks and sovereigns amplified the crisis. Many euro area banks were weakly capitalised when crisis started, due to excessive lending, mainly to the housing sector. Declining valuations of bank assets reinforced capital shortfalls and led to sharp increases in bank solvency and liquidity risk measures (Figure 3). Since the banks, in many cases, were not able to obtain new capital in the market, their recapitalisation needs exacerbated the deteriorating fiscal situation of their sovereigns. On the other hand, euro area banks were important buyers of sovereign bonds and concerns about their ability to continue to do so reinforced the concerns about the solvency of the sovereigns. The doom loop between banks and their sovereigns gradually weakened in the aftermath of the euro area sovereign debt crisis, following the announcement of the Outright Monetary Transactions programme and agreements on the banking union and the fiscal compact (Figure 4).

Even though the acute phase of the crisis subsided and the situation has normalised, the underlying causes of the crisis, including the policy failures that allowed the build-up of 
imbalances, were not fully addressed. In pre-crisis times, the windfall from declining interest rates and debt payments was not saved and higher revenues during boom years were wrongly considered permanent (Allard et al., 2013). When crisis started, national fiscal policies in many countries were forced to tighten rapidly during the downturn to restore market confidence in sovereign borrowing (Figure 5).

There is a risk that the current cyclical upswing will be incorrectly interpreted as an improvement in resilience, at the crucial juncture when further reforms are needed to ensure long-term sustainability of the euro area. After a decade of lacklustre performance, the euro area economy is expanding again and the economic outcomes across the euro area are getting more aligned again (Figure 6). This window of opportunity should be used to reduce the high levels of public debt and for further reforms, in particular further reducing and sharing risks, completing the banking union and correcting the remaining macroeconomic imbalances.

Figure 3. Bank solvency risk increased strongly in the crisis

Credit default swap rates ${ }^{1}$, basis points

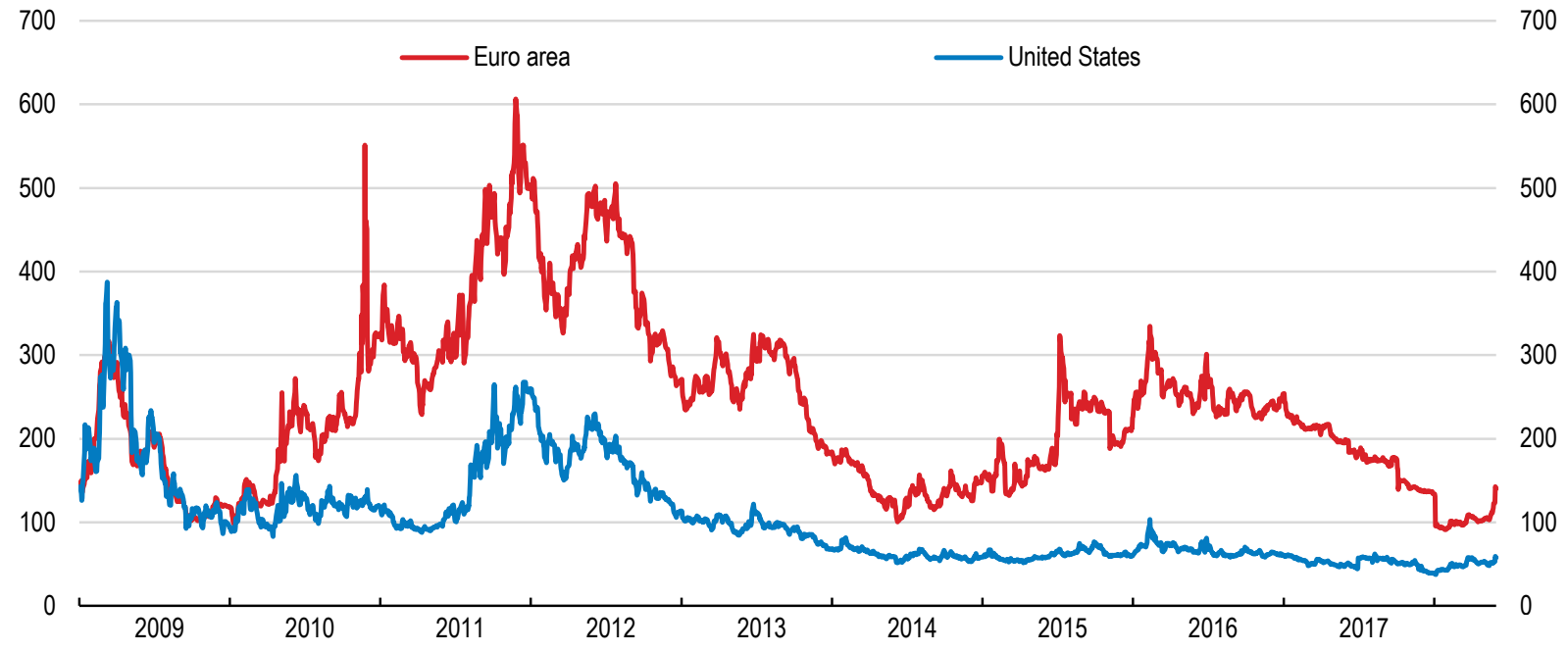

1. Banking-sector five-year credit default swap rates.

Source: Thomson Reuters (2018), Datastream Database.

StatLink 제패 http://dx.doi.org/10.1787/888933741637 
Figure 4. The potentially harmful link between banks and sovereigns gradually weakened in the aftermath of the financial crisis

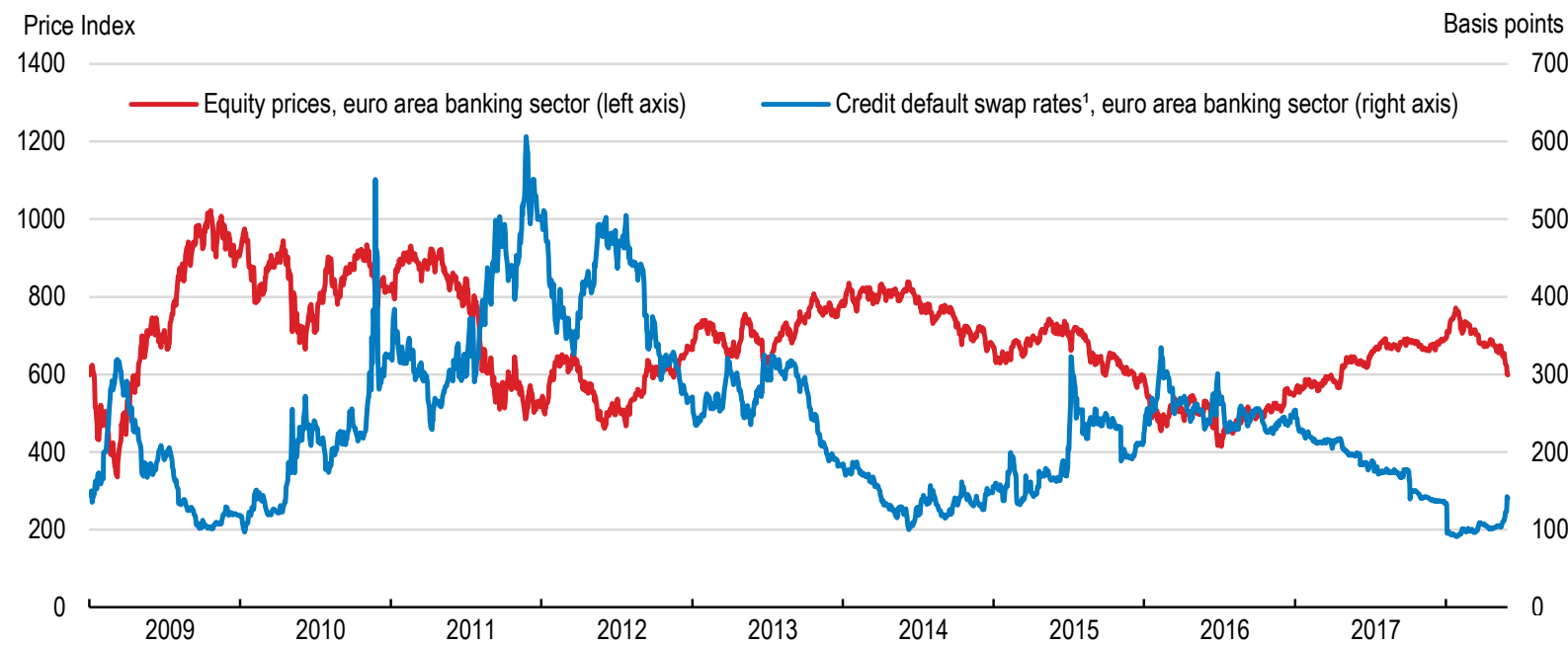

1. Banking-sector five-year credit default swap rates.

Source: Thomson Reuters (2018), Datastream Database.

StatLink 젶ㄴ http://dx.doi.org/10.1787/888933741656

Figure 5. After the crisis, fiscal policy was not very supportive

Annual data, 2008-2017

Annual change in the underlying government primary balance ( $\%$ of potential GDP)

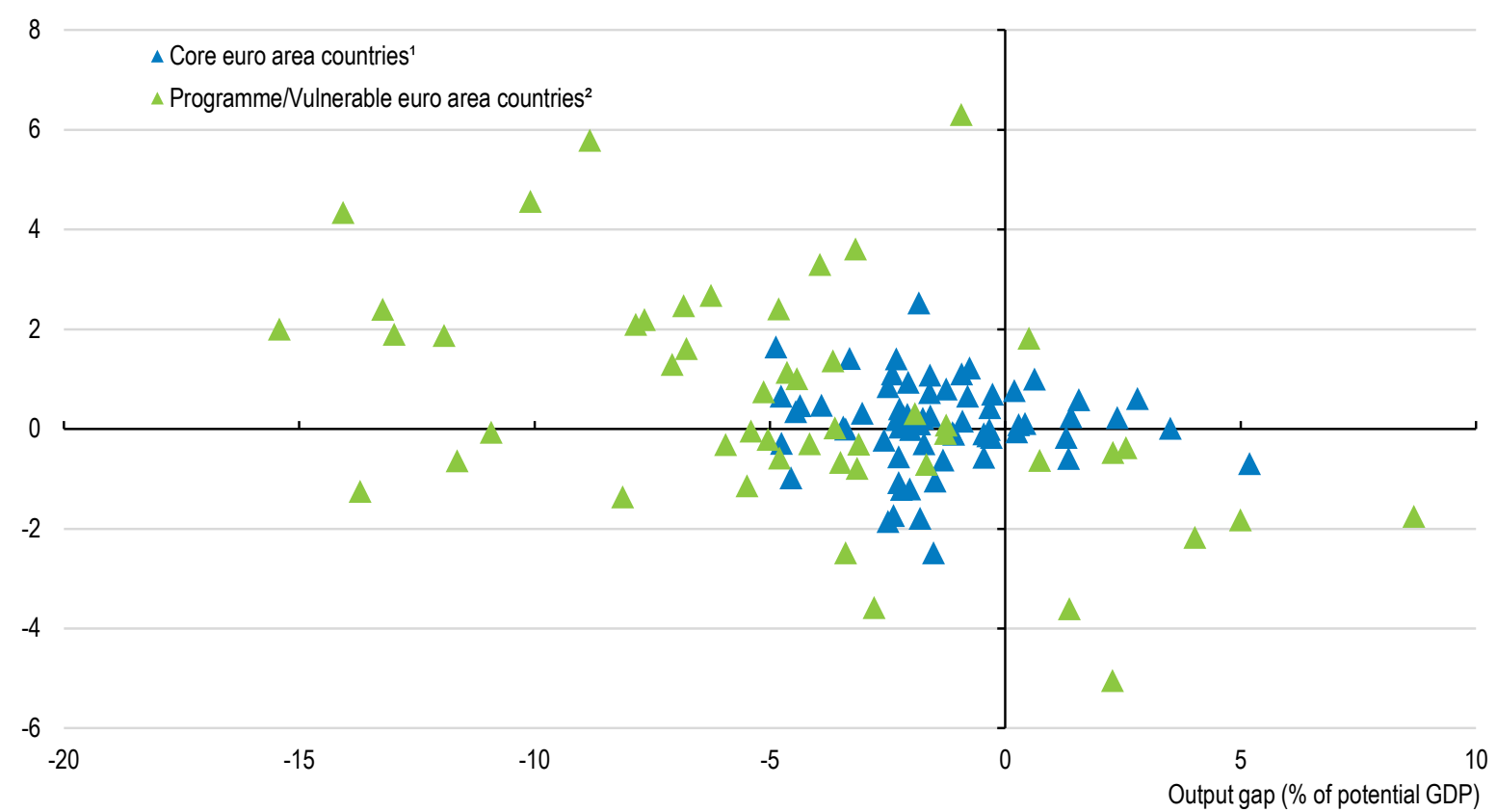

1. Core euro area countries include Austria, Belgium, Finland, France, Germany, Luxembourg and the Netherlands.

2. Vulnerable euro area countries include Greece, Ireland, Italy, Portugal and Spain.

Source: OECD (2018), OECD Economic Outlook: Statistics and Projections (database).

StatLink त्ञाज http://dx.doi.org/10.1787/888933741675 
Figure 6. Dispersion of economic performance in the euro area is decreasing again

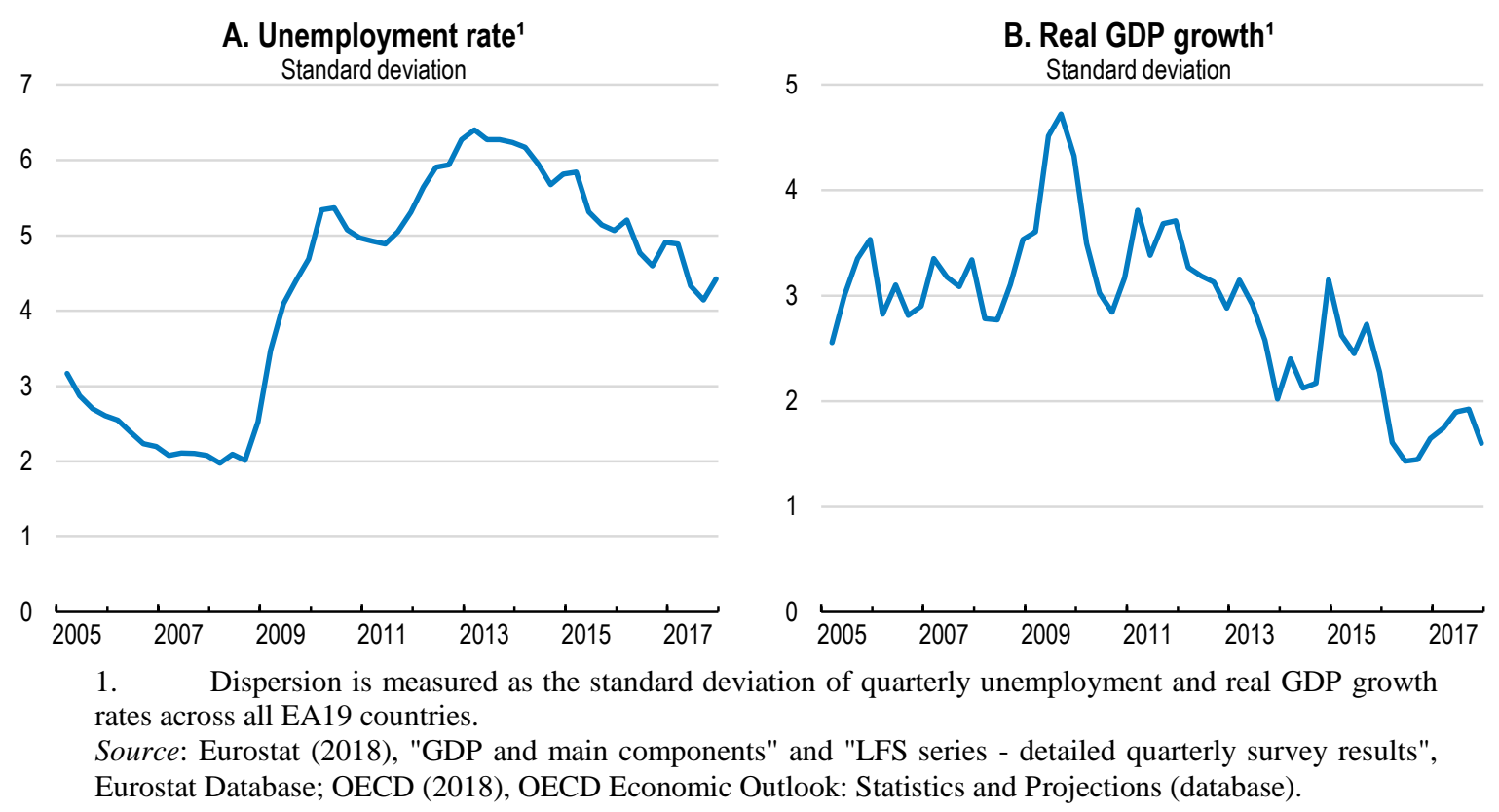

StatLink ज्ञात http://dx.doi.org/10.1787/888933741694

\section{Risk sharing channels in the euro area are insufficient}

In case of a significant country-specific negative shock, the euro area countries cannot use independent monetary policy or exchange rate depreciation to support growth and employment. They can rely on national fiscal policy, but its effectiveness will, as in any open economy, be limited by trade leakages within the European Union, and will not be supported by labour mobility, which is relatively low. Since labour mobility remains low, private risk sharing in Europe usually takes place through cross-border flows of capital and credit. International capital flows lead to more geographically diversified portfolios that are less correlated with domestic income, while cross-border credit flows facilitate consumption smoothing in the aftermath of a country-specific shock.

Despite recent progress with the banking and capital markets unions, financial intermediation in Europe is primarily bank based (Figure 7) and financial markets remain fragmented along national lines (Figure 8). As a result of the bank-bias and cross-border fragmentation, the level of private risk-sharing compared to federations like the United States, Canada or Germany tends to be considerably lower and biased towards credit, rather than capital flows (Allard et al., 2013). Although high pre-crisis levels of crossborder financial integration were partly driven by unsustainable business models and mispricing of risks, the sharp drop in interbank loans at the end of 2008 suggests that, at least in the absence of a functioning banking union, risk sharing through the bank lending channel may break down in period of crisis, exactly when needed the most (Furceri and Zdzienicka, 2015).

Public risk sharing usually takes place through fiscal transfers, such as a centralised unemployment scheme or various equalisation payments. Such channels are virtually non-existent at the euro area and the EU level. Federal states typically allocate significant resources at the federal level, with regional spending just below 50\% (and some 75\% in Canada). In comparison, the EU budget represents some $2 \%$ of member states' total expenditure and none of its tools is meant specifically for macroeconomic stabilisation. 
Similarly, the European Stability Mechanism's (ESM) lending capacity of EUR 500 billion, which represents about $10 \%$ of the euro area's countries combined budgets, is designed to prevent fiscal transfers between countries.

\section{Figure 7. Financial intermediation is mainly bank based}

Outstanding loans ${ }^{1}$ and bonds of non-financial corporations as a percentage of GDP, period average

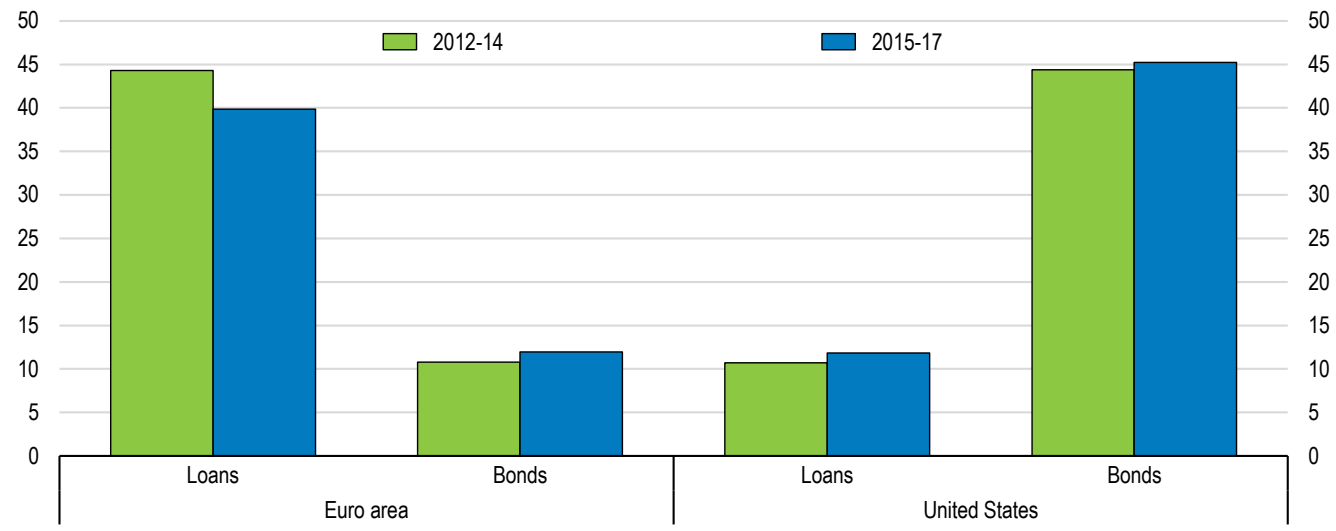

1. Loans of monetary and financial institutions.

Source: Eurostat, European Central Bank, US Bureau of Economic Analysis, Board of Governors of the Federal Reserve System, and Securities Industry and Financial Markets Association.

StatLink 세애 http://dx.doi.org/10.1787/888933741713

Figure 8. Cross-border positions of euro area monetary financial institutions remain limited Per cent ${ }^{1}$
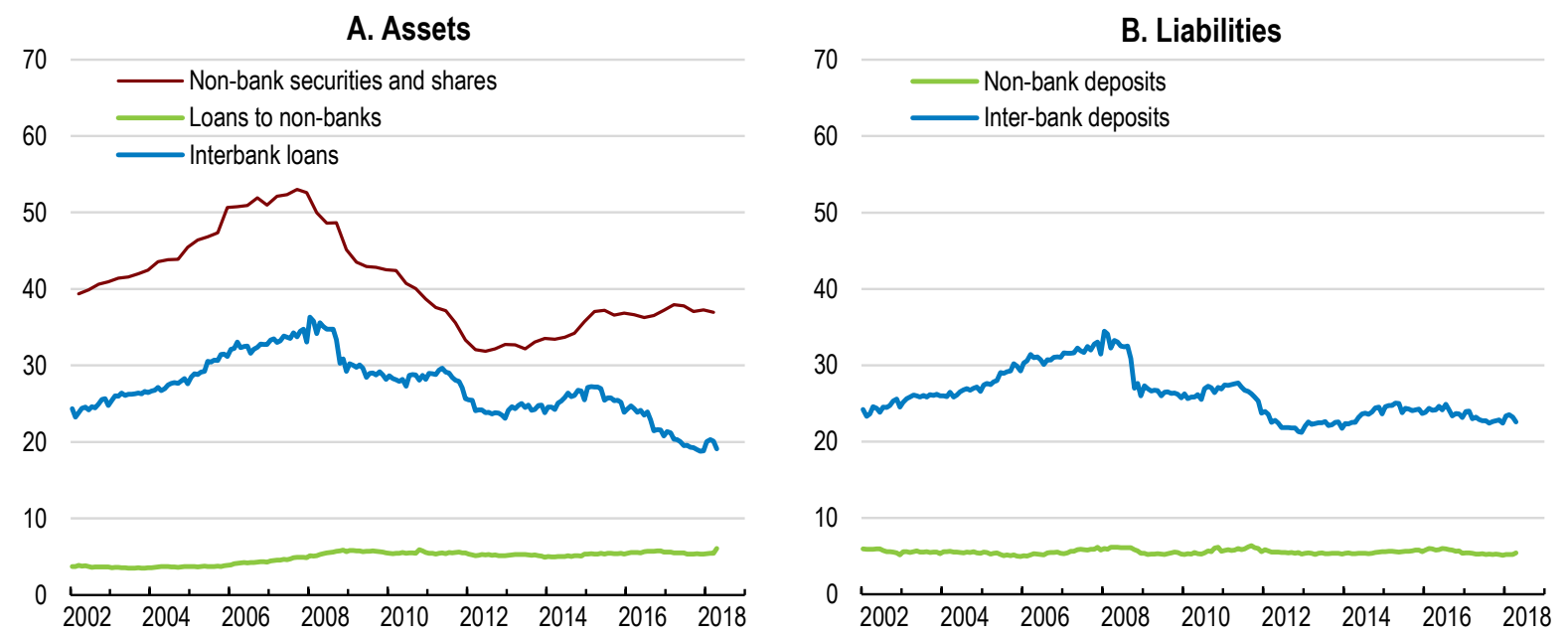

1. Cross-border activity as a percentage of the total provision of financial services in the euro area.

Source: ECB (2018), "MFI balance sheets: Monetary statistics", Statistical Data Warehouse, European Central Bank.

\section{StatLink त्ञाI}

The empirical studies of the risk sharing channels in federal systems show important heterogeneity among countries. For the United States, Asdrubali et al. (1996) find that between 1963 and 1990 some $75 \%$ of the shocks to per capita state gross product were smoothed, mainly through capital and credit markets. In European OECD countries, less than a half of the GDP shocks between 1966 and 1990 were smoothed, roughly one half 
by fiscal transfers and another half by private savings (Sørensen and Yosha, 1998). Further studies of European Union countries confirmed that only $30 \%$ to $40 \%$ of GDP shocks are smoothed, mainly by social benefits (Afonso and Furceri, 2008). If anything, risk sharing in the euro area seems to have deteriorated in the aftermath of the financial crisis when more than $70 \%$ of shocks remained unsmoothed (Milano and Reichlin, 2017). On the other hand, to the extent to which they alleviated the debt burden through delayed repayment and interest rate reductions, the financial assistance instruments introduced during the European sovereign debt crisis increased the euro area's risk sharing capacity (Cimadomo et al., 2017).

Public risk sharing channels, such as a common fiscal stabilisation function, will remain essential, though, as private risk sharing will not be sufficient to accommodate major adverse shocks. Firstly, a symmetric negative shock cannot be smoothed, and may even be amplified, by private risk sharing alone, while monetary and national fiscal policies may be constrained, requiring further support from a common stabilisation tool. Secondly, private risk sharing may not be sufficient when agents fail to internalise the social benefits from private risk sharing and public institutions may need to reassure markets by providing a minimum level of shock absorption (Farhi and Werning, 2012).

\section{Many measures have already been taken, but progress on remaining issues is needed}

Many steps to fill the gaps revealed by the crisis have already been taken. Since the euro area sovereign debt crisis has been exacerbated by the absence of a lender of last resort, the euro area countries agreed in 2012 to create the European Stabilisation Mechanism as a lender of last resort for solvent sovereigns that had temporarily lost market access, provided they accepted a macroeconomic stabilisation programme (Box 1). In addition, the banking union was created to ensure consistent application of rules, both regarding to supervision (Single Supervision Mechanism, 2014) and resolution (Single Resolution Mechanism, 2016), and to break the doom loop between national banking sectors and their sovereigns by ensuring that shareholders and creditors of banks contribute through the application of the bail-in rules to any potential losses.

\section{Box 1. The European Stability Mechanism in the crisis}

The European Stability Mechanism (ESM) offers support to euro area countries with financing difficulties, when necessary to safeguard the financial stability of the euro area. In doing so, the ESM uses three main instruments: (i) lending to governments as part of a macroeconomic adjustment programme, (ii) precautionary financial assistance in the form of credit lines to countries meeting certain conditions, and (iii) lending for bank recapitalisation. Since its inception, the ESM has provided loans conditional on a macroeconomic adjustment programme to Cyprus ${ }^{1,2}$ and Greece, while Ireland, Greece and Portugal benefited from similar facilities by its precursor, the European Financial Stability Facility. In addition, the ESM provided a loan to Spain targeted at recapitalisation of its banks. At the moment, Greece is the only country still in an ESM programme (planned to end in August 2018), but a first step to regain market access has been made in 2017 when Greece successfully issued its first government bond since 2014.

The ESM has an authorised capital of 704 billion euro, of which 80 billion has been paid in by euro area governments, while the rest can be called by the ESM Board of Governors. Based on its high paid-in capital and preferred creditor status (after the 
International Monetary Fund and excluding the Spanish banking sector programme), the ESM enjoys high credit rating and is able to raise money from investors at very favourable rates. The resources are, in turn, used to finance the ESM assistance programmes at costs that are lower than what the programme countries would be charged in the market, resulting in considerable budget savings for participating countries. Although these financing rates fluctuate according to market conditions and include fees to cover the ESM's operating costs, the savings generated for programme countries in 2016 alone ranged from $0.2 \%$ of GDP in Spain to 5.6\% of GDP in Greece.

${ }^{1}$ Note by Turkey: The information in this document with reference to "Cyprus" relates to the southern part of the Island. There is no single authority representing both Turkish and Greek Cypriot people on the Island. Turkey recognises the Turkish Republic of Northern Cyprus (TRNC). Until a lasting and equitable solution is found within the context of the United Nations, Turkey shall preserve its position concerning the "Cyprus issue".

${ }^{2}$ Note by all the European Union Member States of the OECD and the European Union: The Republic of Cyprus is recognised by all members of the United Nations with the exception of Turkey. The information in this document relates to the area under the effective control of the Government of the Republic of Cyprus.

The Outright Monetary Transactions programme provided for potentially unlimited ECB intervention in the sovereign debt market in support of solvent governments facing temporary liquidity problems. It was put in place in July 2012 with the view of improving the euro area monetary policy transmission and limiting the redenomination risks. It is conditional on country's participation in a European Stability Mechanism's macroeconomic adjustment programme or a precautionary credit line. There was a positive confidence impact on both nominal and real bond yields from the announcement of the scheme and the ECB was able to stabilise sovereign debt markets, particularly in Italy and Spain where pressures were increasing at the time, without triggering the programme (Figure 9).

Figure 9. 10-year government bond nominal yields in Italy and Spain declined after the ECB action

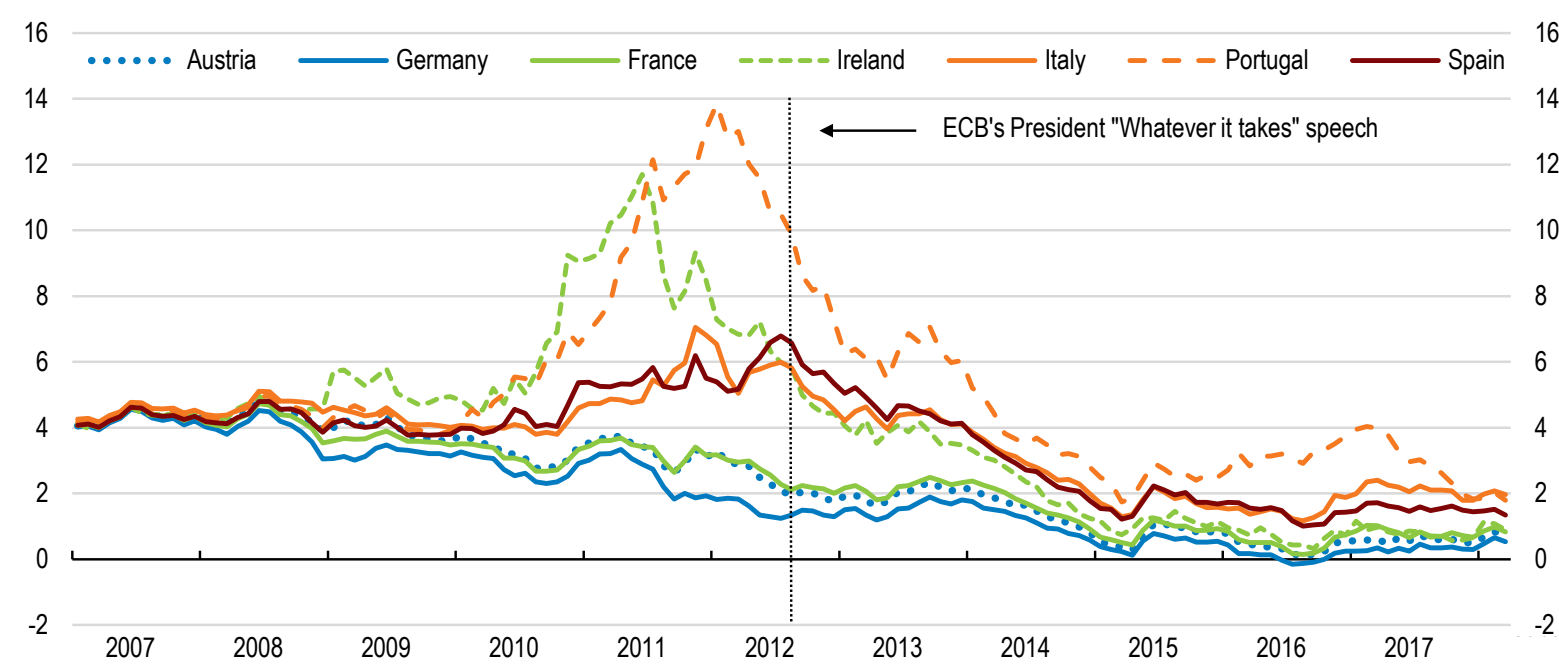

Source: OECD (2018), Key Short-Term Indicators (database). 
Despite the progress made since the euro area debt crisis, important elements of the banking union, such as further risk reduction and a common deposit insurance scheme and the fiscally-neutral backstop to the resolution fund, are still missing. Since private risk sharing may not be sufficient to deal with large negative shocks, public risk sharing channels should be strengthened to provide a common stabilisation tool. Risk sharing through capital markets is under-developed in the euro area and should be developed further.

The rest of the paper looks at the policy instruments for euro area reform in the order of importance (Table 1). We start from the most pressing concern, which is the completion of the banking union needed to reduce the negative loop between banks and sovereigns, such as further risk reduction and risk sharing, and a common deposit insurance scheme. The paper then discusses possibilities for enhancing public risk sharing, namely an introduction of a fiscal stabilisation capacity. Finally, long-term policies for reinforcing private risk sharing through the creation of a genuine capital markets union are discussed.

Table 1. Overview of the euro area reform instruments

\begin{tabular}{|c|c|c|c|c|}
\hline Instrument & Goal & $\begin{array}{c}\text { Time } \\
\text { (years) }\end{array}$ & Technical obstacles & Political obstacles \\
\hline $\begin{array}{l}\text { Fiscal backstop to } \\
\text { the Single } \\
\text { Resolution Fund }\end{array}$ & $\begin{array}{l}\text { Sufficient capacity in resolution, } \\
\text { improved credibility }\end{array}$ & 1 & $\begin{array}{l}\text { None, provided that fiscally } \\
\text { neutral }\end{array}$ & $\begin{array}{l}\text { Reduction of fiscal } \\
\text { revenues }\end{array}$ \\
\hline $\begin{array}{l}\text { Deposit insurance } \\
\text { scheme }\end{array}$ & $\begin{array}{l}\text { Uniform protection of } \\
\text { depositors across euro area }\end{array}$ & 2 & $\begin{array}{l}\text { Re-insurance or full } \\
\text { insurance }\end{array}$ & $\begin{array}{l}\text { Fear of permanent } \\
\text { transfers, moral hazard }\end{array}$ \\
\hline $\begin{array}{l}\text { Reform of } \\
\text { regulatory } \\
\text { treatment of } \\
\text { sovereign } \\
\text { exposures }\end{array}$ & $\begin{array}{l}\text { Diversification of banks' } \\
\text { balance sheets }\end{array}$ & 2 & $\begin{array}{l}\text { Parameters for capital } \\
\text { surcharges; transition } \\
\text { period }\end{array}$ & $\begin{array}{l}\text { Possible financial } \\
\text { instability }\end{array}$ \\
\hline $\begin{array}{l}\text { A European safe } \\
\text { asset }\end{array}$ & $\begin{array}{l}\text { New asset facilitating } \\
\text { diversification of banks' } \\
\text { balance sheets; expanding the } \\
\text { supply of safe assets; } \\
\text { benchmark for European } \\
\text { markets }\end{array}$ & 2 & $\begin{array}{l}\text { For synthetic bonds: } \\
\text { Scaling up potential; pro- } \\
\text { cyclicality of demand } \\
\text { (especially the junior } \\
\text { tranche) }\end{array}$ & $\begin{array}{l}\text { Interaction with national } \\
\text { bond markets; Possible } \\
\text { redistribution across } \\
\text { countries; Possible } \\
\text { financial instability }\end{array}$ \\
\hline $\begin{array}{l}\text { Common fiscal } \\
\text { stabilisation } \\
\text { capacity }\end{array}$ & $\begin{array}{l}\text { Re-insurance against large } \\
\text { macroeconomic shocks }\end{array}$ & 5 & $\begin{array}{l}\text { Difficult parameterisation of } \\
\text { the scheme; }\end{array}$ & $\begin{array}{l}\text { Fear of permanent } \\
\text { transfers }\end{array}$ \\
\hline $\begin{array}{l}\text { Procedures for } \\
\text { sovereign debt } \\
\text { restructuring }\end{array}$ & $\begin{array}{l}\text { Strengthen market discipline; } \\
\text { provide more certainty in } \\
\text { sovereign debt restructuring }\end{array}$ & 5 & $\begin{array}{l}\text { Reducing uncertainty while } \\
\text { avoiding automatic triggers }\end{array}$ & Insolvency often not clear \\
\hline $\begin{array}{l}\text { Develop a } \\
\text { genuine Capital } \\
\text { Markets Union }\end{array}$ & $\begin{array}{l}\text { Deepening and cross-border } \\
\text { integration of capital markets }\end{array}$ & 10 & $\begin{array}{l}\text { Harmonisation of } \\
\text { supervisory, regulatory, } \\
\text { tax, insolvency and legal } \\
\text { practices }\end{array}$ & Diverse national regimes \\
\hline
\end{tabular}

\section{Severing the doom loop by completing the Banking Union}

Durably severing the doom loop between banks and their sovereigns would allow banks to engage in more cross-border financial intermediation, while reducing the fiscal resources governments may have to spend to stabilise banks in the case of crisis, thus making it easier for governments to pursue counter-cyclical fiscal policy. Further steps are needed with regard to risk reduction, including the build-up of liabilities eligible for bail-in, the reduction and prevention of non-performing loans and improvements in the efficiency of the insolvency regimes. 
Despite ongoing progress, the Banking Union is still not reality. While the Single Supervisory Mechanism is fully operational and provides uniform implementation of banking supervision across the euro area, the Single Resolution Mechanism that should provide orderly resolution of failed banks remains incomplete. The "bail-in" component is yet to be tested on a large scale, and the other components of the Banking Union are still missing. In particular, sufficiently financed resolution and deposit insurance funds need to be put in place to ensure credibility of the system. To ensure that the banking union is ready to deal with any eventuality and to strengthen its credibility, swift progress is needed on two missing components, a fiscally-neutral backstop to the already existing Single Resolution Fund and a common deposit insurance scheme.

\section{Unifying the protection of bank deposits}

The Banking Union was created to ensure common standards in banking regulation, supervision and resolution, thus ending the doom loop between national banking sectors and their sovereigns. While a single supervisory mechanism has been put in place and progress has been made in establishing a single resolution mechanism, bank deposits continue to be covered by national deposit schemes with varying available resources, vulnerable to large national shocks. A common deposit guarantee scheme providing a uniform level of confidence in the safety of deposits across the euro area would increase the financial stability benefit for all participating countries, both by spreading risks across a larger pool of financial institutions and by reducing the likelihood that individual payouts will overwhelm the system (ECB, 2016a). While bank funding costs would still vary across the euro area, the differences would reflect differences in bank's risk profile, but not its geographical location (Schoenmaker and Wolff, 2015). Finally, a common deposit guarantee scheme would improve the monetary policy transmission in the euro area by making different forms of money, in this particular case the insured deposits, more homogeneous across euro area countries (Praet, 2017).

However, the link between banks and sovereigns can only be fully severed when banks are no longer backstopped by national government and the national deposit insurance, but at the Banking Union level. As the credibility of a national deposit guarantee scheme is influenced by the fiscal strength of the sovereign, countries with a weaker fiscal position may be viewed as unable to support a national insurance scheme in the face of a systemic financial crisis or a large asymmetric shock. Even in normal times, risk-averse depositors may decide to move their deposits to banks guaranteed by fiscally stronger countries, possibly triggering bank runs.

As with implicit government guarantees, a deposit insurance scheme might lead to moral hazard and banks may take on excessive risks (Schich, 2008). To limit the risk of banks' cross-subsidisation and minimise moral hazard, the insured banks would pay to the European Deposit Insurance Scheme (EDIS) an ex ante risk-based premium (Gros and Schoenmaker, 2014). These risk-based contributions should be based on a common methodology requiring riskier banks - based, among other things, on the level of lossabsorbing capacity, stability and variety of funding sources, business model and management - to pay higher contributions, reflecting their risk profile and other resilience metrics (European Commission, 2015; Allen et al., 2015). The risk premia should also be sensitive to the amount of systemic risk in the banking system (Acharya et al., 2010). To achieve efficiency gains, the administration of EDIS, including decisions on risk-adjusted contributions and management of pay-outs, could be given to the Single Resolution Board, as proposed by the European Commission (European Commission, 2015). This would improve cost efficiency, minimise inter-agency conflicts and allow for swift 
decision making in the crisis (Allen et al., 2011). Such an arrangement is in place in the United States and Japan where the Federal Deposit Insurance Corporation and the Deposit Insurance Corporation of Japan, respectively, combine deposit insurance and resolution powers. Although efficiency gains from jointly running both the resolution fund and the deposit insurance fund are possible, since the administration and investment of both funds require similar know-how and expertise, resources should be clearly earmarked for their respective purposes to avoid the risk that funds for deposit protection are used up in resolution (ECB, 2016b).

The Banking Union can only be completed and thrive if measures for risk reduction and risk sharing go hand in hand. For example, non-performing loans remain elevated in some euro area countries and need to be reduced, prior to further risk sharing. The Commission's proposals regarding the management of existing non-performing loans, including national asset management companies and other measures to develop secondary markets, and the provisioning rules proposed by the Commission and the ECB to prevent the build-up of new non-performing loans are thus welcome. In addition to recent welcome proposals by the Commission aimed at reducing the amount of non-performing loans, further progress is needed in reducing the home bias in sovereign debt exposures of banks.

\section{Diversifying the sovereign debt exposures of banks}

Large exposures of banks to the sovereign debt of their home country continue to exist in many euro area countries (Figure 10). Such exposures link the health of the banking sector to the health of public finances, thus reiterating the potentially destructing link between banks and their sovereigns. To some extent, the link between banks buying substantial amounts of domestic debt may even stabilise sovereign debt markets: under more strict regulation, the effects of panic selling and the flights to safety observed during the crisis could have been more pronounced (Lanotte et al., 2016). However, the experience of the euro area sovereign debt crisis in 2011 and 2012 suggests that the destabilising impact of the "doom loop" exceeds any short-term stabilising effect of domestic banks' buying of their own sovereign debt. 
Figure 10. General government securities held by banks are mainly domestic As a percentage of total MFIs assets ${ }^{1}$, March 2018

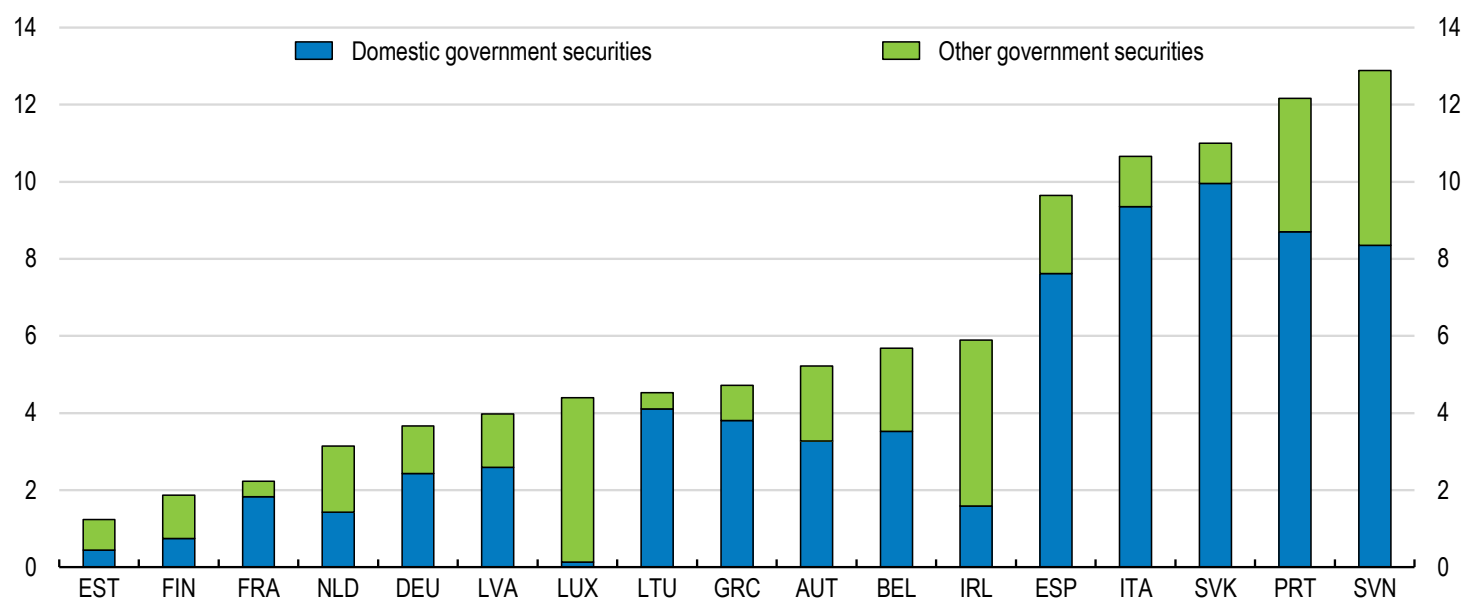

1. Domestic government securities denote own-government securities other than shares held by monetary and financial institutions (excluding central banks). Other government securities refer to other Euro area government securities held by MFIs.

Source: ECB (2018), Statistical Data Warehouse, European Central Bank.

StatLink 에내 http://dx.doi.org/10.1787/888933741770

In most cases, the existing treatment of sovereign exposures is more favourable than other asset classes (BCBS, 2017). The preferential regulatory treatment of sovereign debt exposures comes from favourable treatment of credit risk in the banking book. Provided that assets are held to maturity, certain sovereign exposures may attract zero capital requirements and lower reductions in collateral value (haircuts) when used in collateralised operations, such as repurchase agreements. In addition, zero-risk-weighted sovereign bonds are excluded from the large exposure limit (ESRB, 2015 and Box 2).

\section{Box 2. Current regulatory treatment of sovereign exposures in the euro area}

The existing regulatory treatment of sovereign exposures of banks has recently been reviewed by the Basel Committee on Banking Supervision (BCBS). Although, at this stage, the Committee has not reached a consensus to make any changes to the treatment of sovereign exposures, the review report concluded that the existing rules could potentially exacerbate the negative aspects of the sovereign-bank nexus and that the existing treatment of sovereign exposures is more favourable than other asset classes. Most notably, all countries participating in the BCBS are currently applying a national discretion that allows a zero risk weight for sovereign exposures denominated and funded in domestic currency, regardless of their inherent risk (BCBS, 2017). In addition, sovereign exposures are currently exempted from the large exposures framework and no limits or haircuts are applied to domestic sovereign exposures that are considered highquality liquid assets for purposes of liquidity regulation.

The Basel framework allows two possible approaches to risk weighting, the standardised approach, in which risk weights are assigned using external ratings, mostly by credit rating agencies, and the internal ratings-based approach relying 
on internal models of banks approved by regulators. Credit risk treatment under the standardised approach allows for the national discretion for sovereign exposures denominated and funded in domestic currency, while banks using the internal ratings-based approach are exempted from the $0.03 \%$ floor on the probability of default for sovereign exposures.

In EU law, Basel III standards are implemented by the Capital Requirements Regulation (CRR) and the Capital Requirements Directive (CRD IV). Article 114 of the CRR that applies to banks using the standardised approach contains the national discretion for exposures to sovereign bonds denominated and funded in the domestic currency. However, such treatment seems to ignore the fact that in the euro area the fiscal authority does not have influence on the common monetary authority and the EU Treaty explicitly prohibits monetary financing, which prevents the central bank from fulfilling the sovereign's commitment to an unlimited amount (Lenarčič et al., 2016). In addition, Articles 148 and 150 allow the national competent authorities to extend this discretion also to major banks that are using the internal rating-based approach (the so-called permanent partial use of the standardised approach). These provisions of the Capital Requirements Regulation appear to go beyond the Basel principles governing the use of the standardised approach and were criticised by the Basel Committee as materially non-compliant with Basel III (BCBS, 2014; Véron, 2017). However, in some EU countries, such as Sweden and Belgium, national regulators introduced more stringent treatment of the banks' sovereign exposures. They require banks to assess their sovereign exposures by the internal ratings-based models (Enria, Farkas and Overby, 2016) or impose additional capital buffers available under the Pillar 2 supervisory assessment.

Suggestions for reforming the regulatory treatment of sovereign bonds tend to focus on one or more of three broad possibilities: increasing the zero risk weight on sovereign exposures, gradually introducing large national exposure limits currently not applied to banks' sovereign bond holdings, and introducing an additional capital requirement for concentration risk. Risk-adjusted large exposure limits for sovereign exposures combined with capital requirements based on non-zero risk weights for sovereigns were recently proposed by the German Council of Economic Experts (Andritzky et al. 2016a), while capital surcharges for sovereign concentration risk were recently suggested in a study commissioned by the European Parliament (Véron, 2017).

The first option of non-zero risk weights on sovereign exposures may seem a solution since government debt is never risk-free. However, the implementation of such measure is not straightforward and may further fragment the European financial market. First, potential risk weights must be based on some assessment of sovereign risk. Relying on the assessment of credit rating agencies would go against the trend of reducing reliance on external ratings, which have tended to be backward-looking, pro-cyclical and imperfect indicators of actual default (IMF, 2010; Kiff et al. 2012). That said, some empirical evidence suggests swifter adjustment of European ratings to changed fundamentals since 2010 (Brůha et al., 2017). Alternatively, risk weights could be based on broader indicators, such as debt-to-GDP ratio or the Maastricht criteria more generally (Gros, 2013), but this would weaken the close connection between the credit rating and sovereign credit risk. Finally, the leverage ratio introduced by Basel 3 from 2019 already implies a universal risk weight and hence a non-zero regulatory capital requirement also for sovereign exposures, but it is considered too small by some (Dombret, 2017). 
The second option of exposure limits has the advantage of not imposing automatically additional capital requirement and diversification of banks' portfolios; however, it could amplify pro-cyclical behaviour and generate cliff effects by forcing banks to precipitously sell their sovereign bond holdings. If linked to sovereign credit risk, and thus beyond pure concentration risk, exposure limits could force banks to sell their sovereign bond holdings quickly following a sovereign rating downgrade. To dampen this effect, exposure limits could be linked to long-term averages of sovereign risk measures and bank capital, thus smoothing any required portfolio adjustments. Even if not linked to sovereign risk, exposure limits could act as co-ordinating device for speculative attacks and limit banks' ability to absorb shocks by purchasing sovereign debt in the event of, possibly selffulfilling, sovereign stress (Visco, 2016). However, the existence of a European risk sharing mechanism, such as the Outright Monetary Transactions, should reduce the probability of purely speculative sovereign debt crises and strengthen the disciplining role of relatively strict exposure limits (Frisell, 2016).

Finally, the third option of sovereign concentration charges imposes an additional capital requirement increasing with concentrated sovereign bond holding. The recent proposal by Véron combines zero capital requirements for sovereign exposures below 33\% of Tier 1 capital with gradually increasing capital charges for higher holdings of sovereign debt (Véron, 2017). For exposures to a single sovereign exceeding 33\% of Tier 1 capital, six sovereign exposure brackets would be associated with increasing marginal concentration charges. Simulations using mid-2016 data for euro area banks, excluding outlier banks and assuming no portfolio adjustments, suggest that such gradual concentration charges would imply an additional Tier 1 capital ratio requirement of less than 1.5 percentage points, which banks should be able to meet by subscribing new capital in the markets. Similar, but less stringent parameters for sovereign concentration charges have been proposed by the Basel Committee (BCBS, 2017).

However, the induced portfolio adjustment flows associated with this regulatory reform may be considerable and, according to some estimates, may reduce demand for sovereign bonds or lead to market tensions. To ensure smooth transition, extensive consultations with market participants, a long phase-in periods and grandfathering (i.e. exemption from concentration charges) of all outstanding debt, should be considered.

Given the complexity, the regulatory treatment of sovereign exposures would best be reformed at the global level and when such a consensus is reached in the Basel Committee, European banks should adopt it. If it is not possible to do so, the euro area countries should reconsider the provisions of the Capital Requirements Regulation for the "permanent partial use" of the standardised approach (Box 2).

\section{Creating a European safe asset}

A euro area safe asset would provide banks with an alternative investment instrument to domestic sovereign bonds, thus helping to ensure financial stability during the transition period when banks diversify their sovereign exposures. Since the uncertainty related to the implementation of the reform of sovereign debt exposures of banks is high, it seems advisable to complement concentration charges by other measures (Pagano, 2016). One way to create safe asset is a synthetic safe asset that represents exposure to a basket of sovereign debt of different countries and should be attractive for banks that need to hold low risk euro denominated assets for liquidity and regulatory purposes. The new asset would offer even higher protection than a diversified portfolio of sovereign bonds, as it would be senior to the other tranches (Bénassy-Quéré et al., 2018). 
There was a reduction in the amount of safe assets since the financial crisis, as many safe assets, often securitised and produced by the private sector, lost their safe asset status (Figure 11). Financial engineering, such as the pooling of risks among quasi-safe sovereigns to create a larger share of safe debt from existing public assets, could add another layer of supply of safe assets, provided that pooled assets are sufficiently uncorrelated in the face of common shocks (Caballero et al., 2017).

Figure 11. Safe asset supply has declined

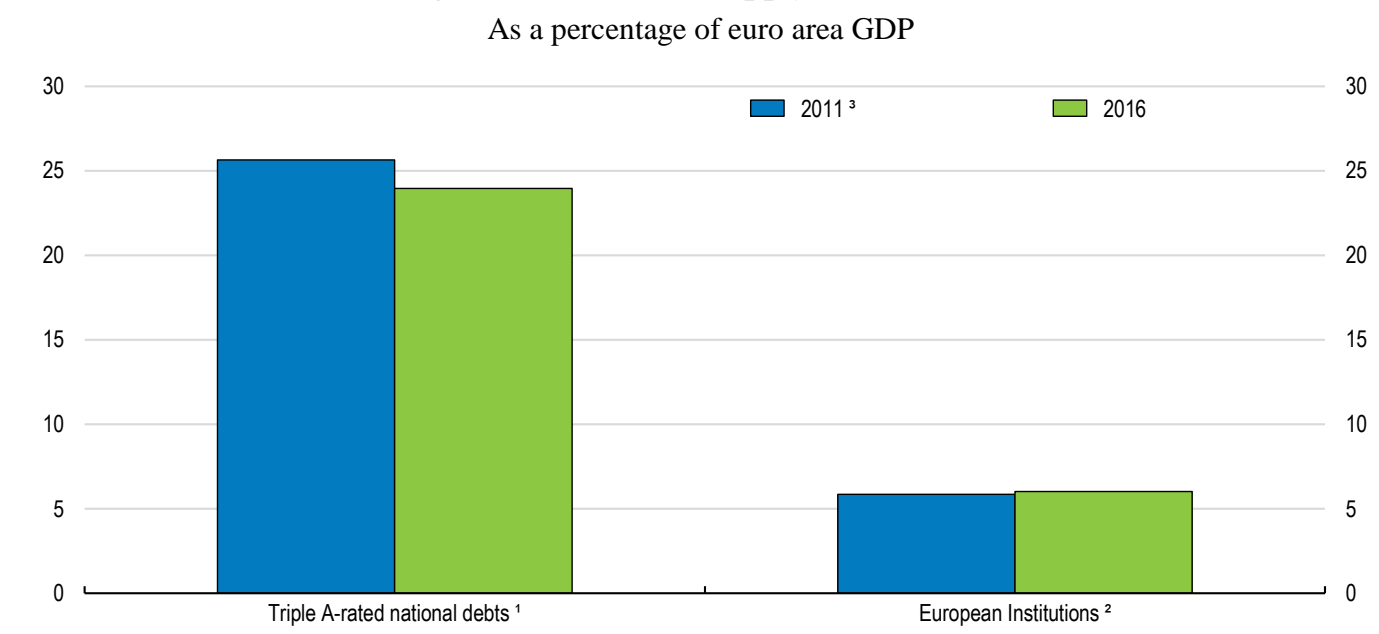

1. Sovereign debt securities issued by the governments of Germany, Luxembourg and the Netherlands.

2. Triple A-rated securities issued by the European Investment Bank (EIB), as well as those issued by EU authorities through the European Stability Mechanism (ESM), the European Financial Stabilisation Mechanism (EFSM), the Balance of Payment facility and the Macro-Financial Assistance Programs.

3. 2013 for European institutions.

Source: Brunnermeier, M. K., Langfield, S., Pagano, M., Reis, R., Van Nieuwerburgh, S., \& Vayanos, D. (2017). ESBies: Safety in the tranches. Economic Policy, 32(90), 175-219; OECD calculations based on public information released by European Institutions.

StatLink त्ञाs http://dx.doi.org/10.1787/888933741789

In the past, there have been several proposals for creating a euro area safe asset. Many early proposals, such as the blue and red bonds (Delpla and von Weizsäcker, 2010) or Eurobills (Philippon and Hellwig, 2014), envisaged debt mutualisation to enhance the safety of these assets, but would also increase the potential for redistribution. More recent proposals tend to avoid debt mutualisation, since some member states are reluctant to do it. Several proposals focus on designing a synthetic asset based on the securitisation of euro area sovereign debt, such as the Sovereign Bond-Backed Security (SBBS) recently proposed by the ESRB high-level task force (Brunnermeier et al., 2017; ESRB, 2018). In addition, the Commission proposed a regulation providing an enabling framework for the development of SBBS (European Commission, 2018a).

Sovereign bond backed securities (SBBS) are synthetic financial product backed by a pooled portfolio of euro area sovereign bonds bought by a public or private entity in either primary or secondary debt markets. Losses on the security are first borne by holders of the junior tranche. Only if losses exceed the part of the portfolio securitised into junior bonds (the subordination level), the senior tranche also suffers a loss. With prudently selected subordination level, senior SBBS can be considered safe, as events leading to a loss on the senior tranche are unlikely. ESRB (2018) tentatively suggests a tranching ratio of $70 \%$ (senior tranche) to $20 \%$ (mezzanine tranche) to $10 \%$ (junior tranche) - although a more conservative ratio may be more appropriate, given the 
empirically high correlation between sovereign bonds and the subdued market reaction to ESBies - and purchasing of sovereign bonds up to 1.5 trillion euro, roughly in accordance with the ECB's capital key. The fact that a significant part of the national sovereign debt would still be traded and be priced by private investors, other than the SBBS issuer, is crucial for retaining the market discipline in the pricing of SBBS (Demary and Matthes, 2017).

The weakest point of the various SBBS proposals is the allocation of the junior tranche. The financial crisis has amply demonstrated that the securitisation techniques only relocate financial risks, but do not eliminate them. If the market for the junior SBBS tranche broke down in the period of market stress, the agency could not go on buying national sovereign bonds and the SBBS concept would collapse.

Other ways of creating a euro area safe asset without risk mutualisation could be considered. Instruments, such as E-bonds issued by a senior intermediary that borrows at large scale in the market and then lends on to national governments (Monti, 2010) or debt issued by a euro area budget authority (Ubide, 2015), could improve the supply of safe assets while not involving an explicit government guarantee. However, their possible drawbacks include reduced liquidity of national bond markets and redistribution of issuance costs across euro area countries, which could increase the average cost of borrowing for some countries (Leandro and Zettelmeyer, 2018). Further analytical work on safe asset alternatives may be needed before deciding on the way forward.

\section{Enhancing common macroeconomic tools to deal with significant adverse shocks}

The existing euro area policies and institutions complemented by those recommended so far in this paper would make all euro area sovereign bonds safer. Firstly, the Outright Monetary Transactions programme has already made sovereign bonds practically immune to liquidity crises. Secondly, the completed banking union, including European Deposit Insurance Scheme and further measures to reduce and share risks, together with efficient diversification of sovereign debt exposures of banks would come a long way to severing the "doom loop" between banks and their sovereign.

However, in case of a significant adverse macro-economic shock, common monetary policy and national fiscal policies may not be enough to smooth activity. A fiscal stabilisation capacity could provide additional risk sharing against large asymmetric and area-wide shocks. Of course, there would still be the risk of sovereign default - and a possible sovereign debt restructuring mechanism should aim at reducing the uncertainty and transaction costs associated with precisely such an event, but the probability of default would be much lower than in the unreformed system. This section is looking at those issues.

\section{Introducing a common fiscal stabilisation capacity}

A fiscal stabilisation function at the euro area level would provide resources to deal with country-specific shocks that cannot be managed at the national level alone because of lack of fiscal space or high marginal borrowing costs. Through enhanced resilience and financial stability, future interventions by the European Stabilisation Mechanism would be less likely, thus saving the pooled financial resources. However, an even more important justification for a common fiscal stabilisation capacity is to deal with common shocks. 
Common, area-wide shocks would normally, as far as they have implications for price stability, be stabilised by monetary policy. However, in periods when monetary policy is constrained by the zero lower bound, coordinated fiscal support may be an important part of the policy mix, especially since national fiscal policies could also be constrained by high spreads. Indeed, empirical studies and theoretical models both suggest that fiscal policy measures that stimulate aggregate demand, such as a temporary increase in government spending, are associated with higher multipliers in recession and at the zero lower bound (Auerbach and Gorodnichenko, 2011; Eggertsson, 2011).

Monetary policy is likely to remain constrained in the near and medium terms. Weak potential growth, implying a low neutral interest rate, and the weak outlook in the euro area for inflation suggest that nominal interest rates may stay close to zero for a prolonged period of time. Large shifts in saving and investment preferences also mean that monetary policy may be more frequently constrained by the zero lower bound (Rachel and Smith, 2017). Unconventional monetary policy may provide some additional accommodation, but its effectiveness may be limited and have undesirable distributional consequences (Orphanides, 2017).

The idea of complementing the monetary union in Europe with some form of fiscal federalism can be traced back to the MacDougall Report suggesting a community budget of $2-2.5 \%$ of GDP and other measures, including a common unemployment fund going "a small part of the way towards creating a situation, in which monetary union could be sustained" (MacDougall et al. 1977, p.13). More recently, the Five Presidents' Report highlighted the key characteristics for such a scheme: it should not lead to permanent transfers between countries, it should not undermine the incentives for sound fiscal policy-making at the national level, it should be consistent with the existing EU fiscal framework and it should not be an instrument for crisis management (Juncker et al., 2015).

Following up on this issue, the European Commission has recently proposed a suite of new budgetary instruments for the euro area stabilisation (European Commission, 2017c). The proposal contains a stabilisation function in one of three forms: an investment protection scheme, a rainy day fund or an unemployment benefit re-insurance scheme. The stabilisation function would in all cases contain both loans and grants, for stronger and more immediate macroeconomic effects. The preferred option of the European Commission seems to be a scheme that protects investment against large country-specific shocks. Such fiscal stabilisation capacity would use pooled resources accumulated in good times through countries' contributions to stabilise member countries hit by adverse shocks, based on an automatic trigger.

The fiscal stabilisation function could also be provided, with weaker impact, through short-term European Stabilisation Mechanism loans. Such loans would be repaid in the course of an economic cycle, conditional on lighter criteria than regular programmes and could be used to stabilise public investment or reward structural reforms (Strauch, 2018). However, such strengthening of the preventive capacity would require changes in the European Stabilisation Mechanism's mandate that would make it more like the European Investment Bank, an independent EU body with its own capital, for which the ESM Treaty would need to change.

From the macroeconomic stabilisation point of view, the precise form of the fiscal stabilisation function does not seem to matter much, as money is fungible. In this paper, as one part of the fiscal stabilisation package, we propose a European unemployment benefits re-insurance scheme that would be complementary to other possible schemes 
providing short-term nondiscretionary transfers (Berger et al., 2018). Unemployment is a key aspect of business cycles and unemployment insurance is therefore a natural and powerful automatic stabiliser (Beblavý et al., 2015). In practice, the scheme would cover only a portion of large negative shocks, based on small contributions from all member states (in times when the balance of the fund is close to zero) combined with gradually increasing contributions from countries that have benefited from its support (Figure 12).

Figure 12. European unemployment fund would reinsure the existing national schemes

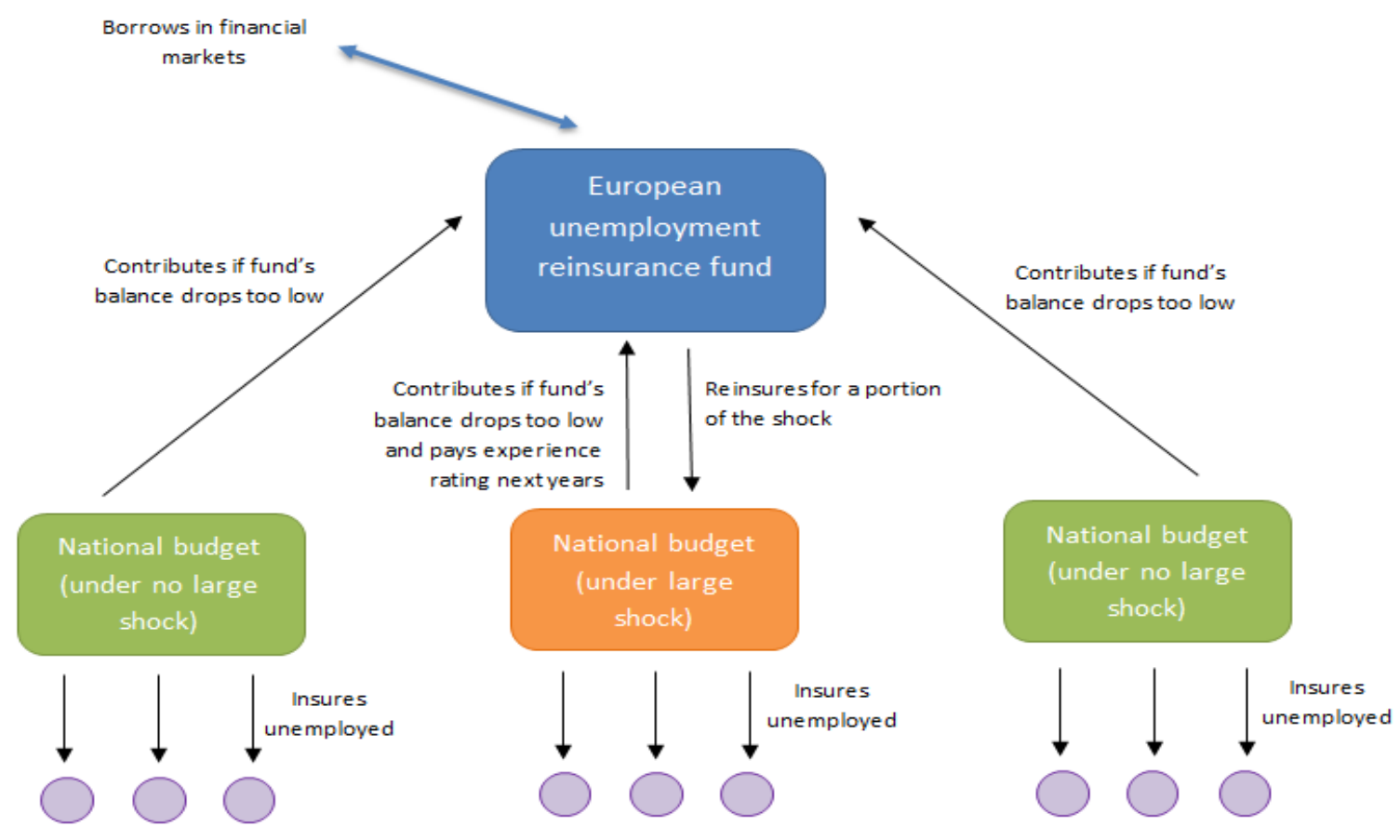

Source: Claveres and Stráský (2018).

The capacity should be activated when unemployment rate is both increasing and above the long-term average. Pay-outs from the scheme would be proportional to the unemployment increase, reflecting the pressure on public finances. Such a set-up would cease support when the unemployment rate stops increasing. Since countries with stable unemployment would stop receiving pay-outs, incentives for countries to reform their labour markets and lower structural unemployment would be preserved. To ensure that permanent transfers are avoided in the long-run, a slow-moving memory mechanism would be applied to link increases in net contributions to the scheme with the number of times a country has drawn on the scheme. Since the scheme would only re-insure national agencies up to a pre-defined transfer amount that would have to be broadly repaid, euro area countries would remain free to decide the details of their national unemployment benefit systems.

The scheme should be able to borrow in financial markets, under conditions similar to the European Stability Mechanism, so as to finance occasional deficits when accumulated contributions do not suffice to cover the pay-outs. Preliminary simulation results suggest that the debt issuance during the financial crisis would stay below $2 \%$ of the euro area 
GDP, not enough to materially increase the supply of debt by European super-national institutions (Claveres and Stráský, 2018; Figure 13).

Figure 13. Outstanding debt of European Institutions is low

EUR billions, end-of-year 2015 stocks

500

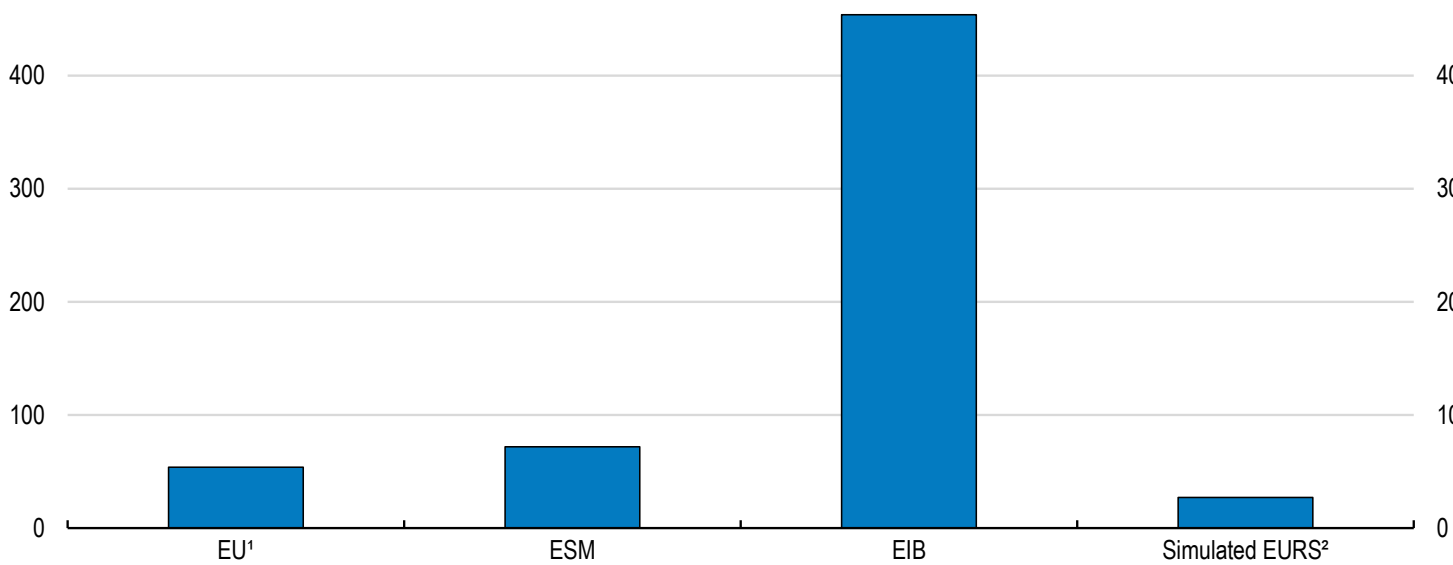

1. EU includes the European Financial Stability Mechanism, Balance of Payment Facility and MacroFinancial Assistance Programs.

Source: European Systemic Risk Board (2017) and Claveres and Stráský (2018).

StatLink ज्ञाs http://dx.doi.org/10.1787/888933741808

The macroeconomic stabilisation outcomes of the proposed unemployment re-insurance scheme with a double condition trigger and experience rating from a stylised macroeconomic model simulated using historical data from 2000 to 2016 suggest that such a scheme could prevent permanent transfers between countries, while contributing positively to euro area macroeconomic stabilisation (Box 3). For an average annual contribution of $0.17 \%$ of GDP, the scheme would have reduced the average standard deviation of GDP growth from 2009 to 2013 by $0.36 \%$ and the euro area GDP in 2009 would have been $1.05 \%$ higher. Such results are in line with results from similar studies. An IMF study identified that contributions between $1.5 \%$ and $2.5 \%$ of GDP would be needed to smooth income shocks in the euro area effectively (Allard et al., 2013). 
Box 3. Counterfactual simulations of the euro area unemployment re-insurance scheme for 2000-2016

Trigger: The reinsurance activates according to a double-condition trigger when the unemployment rate is increasing from the previous year and above its 10-year average.

Payment: Upon its activation, the scheme reinsures the national agency with an amount equivalent to $1 \%$ of GDP times the change in the unemployment rate. This means that a country experiencing a $1 \%$ hike in unemployment (with current rate above the 10-year average) would receive transfer amounting to $1 \%$ of its GDP. Hence payment is proportionated to the unemployment hike. Cumulative net balances towards the fund are capped at 5\% of GDP.

Financing: Every country contributes the equivalent of $0.1 \%$ of GDP each year if the fund's balance falls below $-0.5 \%$ of total GDP the previous year. In addition, countries pay a premium due to experience rating if applicable. The fund is assumed to be able to borrow in financial markets.

Experience rating: For each time the trigger was activated over the past 10 years, an additional contribution is paid amounting to $0.05 \%$ of GDP. Hence, at maximum if the fund activated 10 times the premium amounts to $0.1 \%$ of GDP for a total of $0.6 \%$ if there is an annual contribution.

Multiplier: Deciding on a multiplier to assess the stabilisation impact of the scheme is not trivial and subject to an extensive literature. Following Beblavý et al. (2015), we choose the conservative estimate of 1.5.

Based on these design features, we run a counterfactual analysis for European countries from 2000 to 2016, based on data availability. The scheme would have been activated in about one third of country-years and mobilized an average annual contribution from countries of $0.17 \%$ of GDP. In terms of stabilisation, it would have reduced the average standard deviation of GDP growth from 2009 to 2013 by $0.36 \%$. The euro area GDP would have been $1.05 \%$ higher in 2009 (Figure 14). The fund's balance would have fluctuated between -0.7 and $0 \%$ of the euro area's GDP from 2000 to 2008, before decreasing due to the financial crisis in 2008. At the lowest, it would have settled at $-1.97 \%$ of total GDP at the peak of the sovereign debt crisis in 2013 before increasing to $-1.16 \%$ in 2017 (Figure 15). 
Figure 14. Macroeconomic stabilisation properties of the simulated EURS Euro area real GDP growth

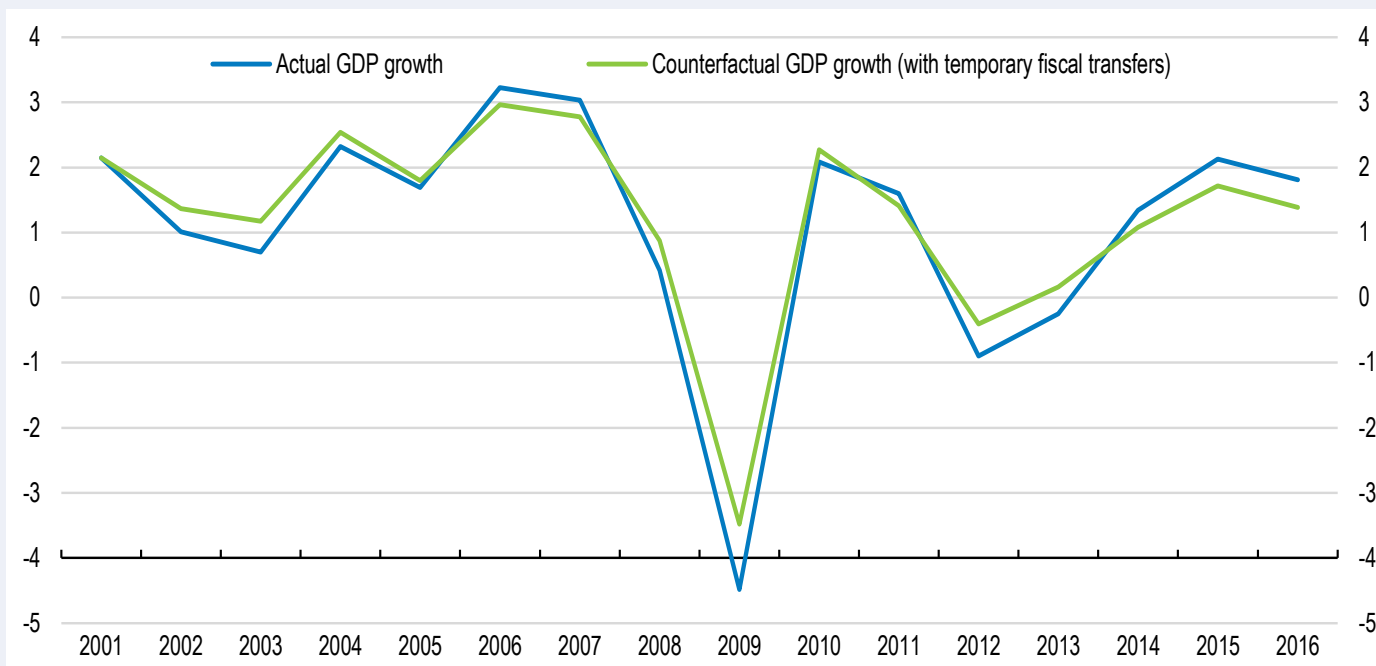

Source: OECD (2018), OECD Economic Outlook: Statistics and Projections (database) and authors' calculations.

StatLink त्माs http://dx.doi.org/10.1787/888933741827

Figure 15. Cumulated balance of the simulated EURS

As a percentage of euro area GDP ${ }^{1}$

0.5

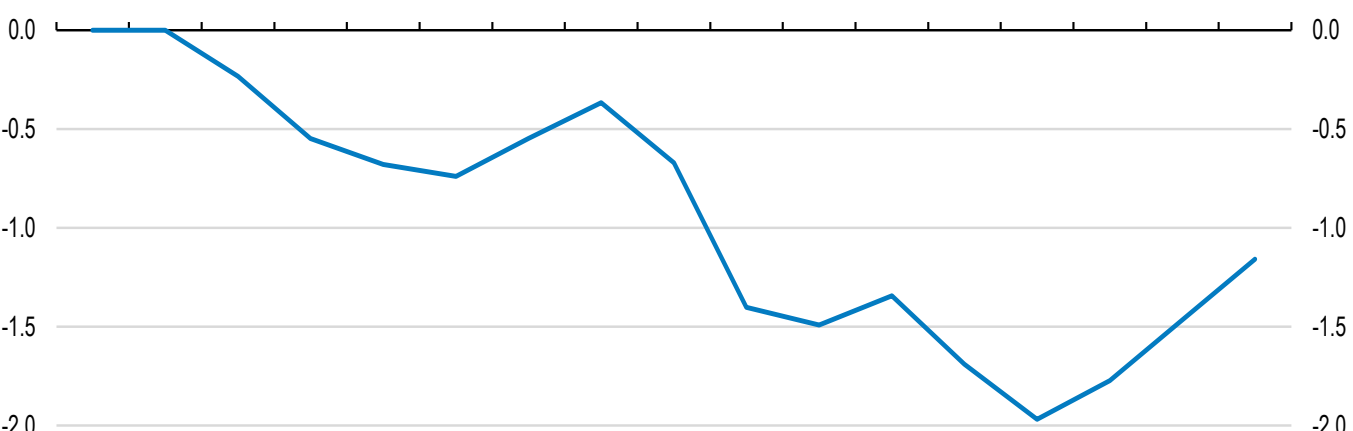

$\begin{array}{lllllllllllllllllll}-2.5 & 2000 & 2001 & 2002 & 2003 & 2004 & 2005 & 2006 & 2007 & 2008 & 2009 & 2010 & 2011 & 2012 & 2013 & 2014 & 2015 & 2016 & -2.5\end{array}$

1. Based on the parameterisation discussed above and the annual GDP data from the $O E C D$ Economic Outlook: Statistics and Projections (database), May.

Source: Claveres and Stráský (2018).

StatLink त्गाsम http://dx.doi.org/10.1787/888933741846

The annual net balances would have ranged from $-0.55 \%$ (Portugal in 2014) to $3.6 \%$ of GDP (Ireland in 2009). Countries would have been alternatively contributors or recipients to the fund, avoiding permanent transfers (Table 2), expect for Estonia and Latvia which only join the scheme in later years. Germany and Austria would have received transfers from 2002 to 2005 and then have contributed in net terms until the 
end of the period due to experience rating. France, Italy, Ireland or Spain would not have triggered the reinsurance until the 2008 crisis, and would have made payments due to the start-stop mechanism to keep it afloat, while Portugal would have switched between being a net recipient and net contributor frequently during the period. The trigger would have activated the fund in most countries in 2008-2009, and again in 2013.

Table 2. Transfers to and from the unemployment benefit re-insurance scheme

\begin{tabular}{|c|c|c|c|c|c|c|c|c|c|c|c|c|c|c|c|c|}
\hline $\begin{array}{c}\text { As } \% \\
\text { of } \\
\text { GDP }\end{array}$ & AUT & BEL & DEU & ESP & EST & FIN & FRA & GRC & $\mathrm{IRL}$ & ITA & LUX & LVA & NLD & PRT & SVK & SVN \\
\hline 2000 & 0.0 & 0.0 & & 0.0 & & 0.0 & 0.0 & & 0.0 & 0.0 & 0.0 & & 0.0 & 0.0 & & \\
\hline 2001 & 0.0 & 0.0 & & 0.0 & & 0.0 & 0.0 & & 0.0 & 0.0 & 0.0 & & 0.0 & 0.0 & & \\
\hline 2002 & 0.3 & 0.0 & 0.8 & 0.0 & & 0.0 & 0.0 & & 0.0 & 0.0 & 0.3 & & 0.0 & 0.0 & & \\
\hline 2003 & 0.3 & 0.0 & 1.0 & 0.0 & & 0.0 & 0.0 & & 0.0 & 0.0 & 0.8 & & 0.0 & 1.3 & & \\
\hline 2004 & 1.0 & -0.1 & 0.4 & -0.10 & & -0.1 & -0.1 & & -0.1 & -0.1 & 0.2 & & 0.7 & 0.2 & & \\
\hline 2005 & -0.1 & 0.0 & 0.4 & -0.1 & & -0.1 & -0.1 & & -0.1 & -0.1 & 0.2 & & 0.0 & 0.7 & & \\
\hline 2006 & -0.3 & -0.2 & -0.3 & -0.1 & & -0.1 & -0.1 & -0.1 & -0.1 & -0.1 & -0.2 & & -0.2 & -0.2 & & \\
\hline 2007 & -0.3 & -0.2 & -0.3 & -0.1 & & -0.1 & -0.1 & -0.1 & -0.1 & -0.1 & -0.4 & & -0.2 & 0.0 & & \\
\hline 2008 & -0.2 & -0.1 & -0.2 & 3.0 & & 0.0 & 0.0 & 0.0 & 1.7 & 0.0 & -0.3 & & -0.1 & -0.3 & & \\
\hline 2009 & 0.9 & 0.8 & -0.3 & 2.3 & & -0.1 & 1.6 & -0.1 & 3.6 & -0.1 & 1.0 & & 1.0 & 1.5 & & \\
\hline 2010 & -0.4 & 0.2 & -0.3 & 0.0 & & 0.0 & 0.0 & 3.0 & 0.1 & 0.5 & -0.1 & & 0.4 & 1.0 & -0.1 & 1.3 \\
\hline 2011 & -0.4 & -0.3 & -0.3 & 0.0 & -0.1 & -0.2 & -0.2 & 2.2 & 0.1 & -0.1 & -0.5 & & -0.3 & 0.8 & -0.1 & 0.8 \\
\hline 2012 & 0.0 & -0.3 & -0.3 & -0.2 & -0.1 & -0.2 & 0.4 & -0.2 & -0.3 & 2.1 & 0.0 & & 0.6 & -0.2 & -0.1 & 0.5 \\
\hline 2013 & 0.1 & 0.7 & -0.3 & -0.1 & -0.1 & 0.3 & 0.3 & -0.3 & -0.4 & 1.2 & 0.3 & & 1.0 & -0.1 & 0.2 & 1.0 \\
\hline 2014 & -0.1 & -0.2 & -0.2 & -0.4 & -0.1 & 0.3 & -0.3 & -0.3 & -0.4 & 0.2 & -0.2 & -0.1 & -0.2 & -0.6 & -0.2 & -0.3 \\
\hline 2015 & -0.2 & -0.4 & -0.2 & -0.4 & -0.1 & 0.5 & -0.3 & -0.3 & -0.4 & -0.4 & -0.5 & -0.1 & -0.4 & -0.5 & -0.2 & -0.3 \\
\hline 2016 & -0.1 & -0.3 & -0.1 & -0.4 & -0.1 & -0.3 & -0.4 & -0.3 & -0.4 & -0.4 & -0.4 & -0.1 & -0.4 & -0.5 & -0.2 & -0.3 \\
\hline
\end{tabular}

Note: Negative values are contributions to the funds and positives values are payments from it.

\section{Improving market discipline through better procedures for sovereign debt restructuring}

Public risk sharing using fiscal instruments, such as the unemployment benefit reinsurance scheme, provides coverage against adverse shocks. To minimise moral hazard and the risk of permanent transfers, access to the unemployment benefit re-insurance scheme should be conditional on past compliance with the European fiscal framework.

The euro area sovereign debt crisis and the Greek sovereign debt restructuring have amply demonstrated that sovereign debt is not zero risk. In fact, the sovereign default risk is likely to be higher in the euro area since the ECB is prohibited to finance government debt (De Grauwe and Ji, 2013). In case of sovereign bankruptcy and to reduce the burden for the sovereign, the European Stability Mechanism could be given a bigger role in making the settlement with private creditors more predictable and transparent. Such framework would not contain any automatic triggers, such as extension of maturities, but rather improvements in the existing framework, such as the reform of existing Collective Action Clauses to prevent lengthy negotiations with holdout investors (Regling, 2018).

To address the problem with creditors who refuse to participate in debt restructuring and hold out with the view of receiving payment in full, the treaty establishing the European Stability Mechanism already requires euro area countries to include standardised collective action clauses (CACs) in all new debt instruments. However, under these euro- 
area CACs holdout creditors can still block the full restructuring of individual bonds, as the CACs rely both on aggregate and series-by-series voting. In other words, the aggregation feature may not be sufficient - and it is indeed weaker than the mechanism applied in the 2012 Greek debt restructuring where all domestic law bonds were subject to a single vote (Gelpern at al., 2015). Stronger aggregation rule allowing for a single vote across all debt instruments affected by a restructuring (the so-called "one-limb" voting) could considerably streamline the process, as it would make it much harder for potential holdouts to acquire a stake that could block a restructuring (IMF, 2014; Zettelmeyer, 2017). Other measures addressing the weaknesses of the one-limb voting would include a provision ensuring that all creditors are offered identical restructuring terms (Andritzky et al., 2016b).

\section{Reinforcing private risk sharing through the Capital Markets Union}

Completed banking union with cross-border banks would improve monetary policy transmission and remove the need for fiscal backstop at the national level. However, private risk sharing through the banking system should be reinforced by continuing integration of capital markets, further reducing the reliance on bank financing and the need for complementary public sector risk sharing. The creation of a genuine Capital Markets Union involves harmonisation of supervisory, regulatory, tax and legal practices, which are policy areas where member countries retain important competences and where progress in the past has been slow. Although the process of building the Capital Markets Union is likely to stretch over many years, because financial ecosystem can only change slowly, its potential benefits are substantial and should be pursued with determination. At the current juncture, the home bias that we have encountered in sovereign bond holdings of banks is also present in households' holdings of debt securities and listed shares in many euro area countries (Figure 16).

Figure 16. Financial assets held by households are mainly domestic

Q4 2017
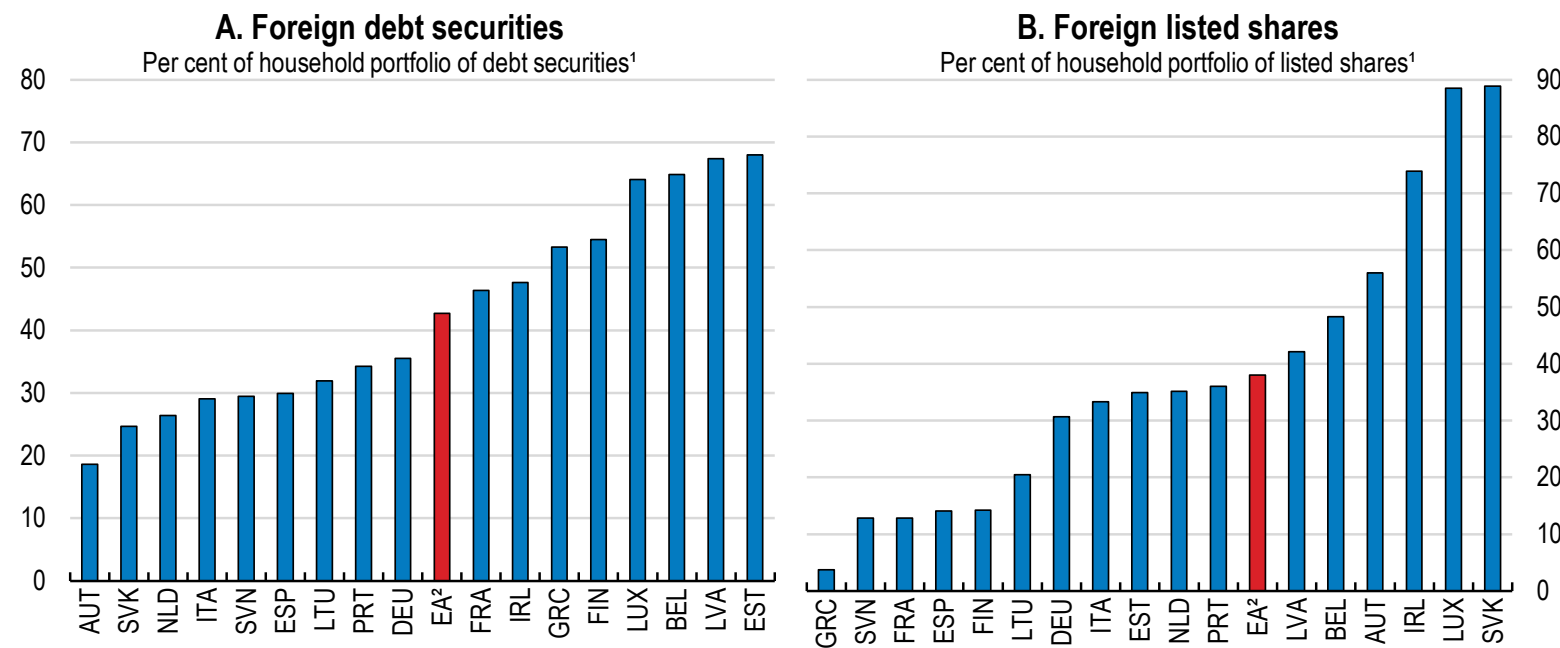

1. Households and non-profit institutions serving households.

2. Euro area member countries that are also members of the OECD (16 countries)

Source: ECB (2018), "Quarterly Sector Accounts”, Statistical Data Warehouse, European Central Bank.

StatLink 제패 http://dx.doi.org/10.1787/888933741865 
Well-designed banking and capital market policies could be mutually reinforcing. Progress in completing the banking union will enhance and reinforce the functioning of the Capital Markets Union (CMU). On the other hand, progress in capital markets integration and deepening will help the euro area economy to become less reliant on bank financing, while allowing banks to exploit the cross-border economics of scale (Constâncio, 2017).

Differences in national insolvency regimes can create an important barrier to crosscountry investment and legal uncertainty, complicating credit risk assessment by investors, resolution of non-performing loans and an efficient restructuring of viable companies. Cross-border proceedings are particularly costly taking three years on average and being twice as expensive as domestic insolvency proceedings (European Commission, 2016). New OECD indicators show significant differences across Europe in the design of insolvency regimes (Figure 17, Panel A) and the accompanying analytical work suggests that lack of well-designed insolvency regimes may hinder aggregate productivity growth by delaying the liquidation or restructuring of weak firms (Andrews et al., 2017). Reforms to insolvency regimes can reduce the share of capital sunk in weak firms, spur the reallocation of capital to more productive firms and facilitate technological diffusion (Figure 17, Panel B and C). In countries with weak banks and ill-functioning insolvency frameworks, which entail impediments to corporate restructuring and reduce recovery rates for creditors, efforts to address non-performing loans should be accompanied with insolvency regime reform.

The Commission proposed in December 2016 a directive to further harmonise insolvency proceedings, setting out common principles on early restructuring, so as to allow viable firms to be revitalised rather than liquidated, introducing measures to reduce the length of insolvency procedures and rules for entrepreneurs to benefit from a second chance. These are steps in the right direction. OECD work suggests that a brief time to discharge, allowing creditors to initiate restructuring and having early warning mechanisms are the most important dimensions of insolvency regimes with respect to the effects of reforms on productivity.

In addition, new rules to facilitate debt recovery in cross-border insolvency proceedings entered into force in June 2017. The rules aim at resolving the conflicts of jurisdiction in cross-border insolvency proceedings and ensuring the recognition of insolvency-related judgments across the EU. Thanks to the new regulation, the proceedings opened by courts in an EU country other than the one where the company's registered office is based (socalled secondary proceedings) will be avoidable, easing the restructuring of companies in a cross-border context. The regulation also introduces the group insolvency proceedings and the EU-wide interconnection of electronic national insolvency registers by June 2019.

Regulatory harmonisation in other areas could also facilitate development of cross-border financial markets. Better aligned national regulatory treatment would facilitate crossborder distribution of investment funds and provide more investment opportunities for savers. Similarly, clearer rules for cross-border transaction in claims, such as collateralisation or factoring, would provide legal certainty and unlock additional sources of financing. Recent proposals by the Commission for more harmonised rules on distribution of investment funds, cross-border transactions in claims and regulatory treatment of covered bonds, which represent important source of bank financing in some European countries, are thus welcome (European Commission, 2018b). 
Figure 17. Insolvency regimes vary considerably across countries

\section{A. The design of insolvency regimes across countries, 2016}
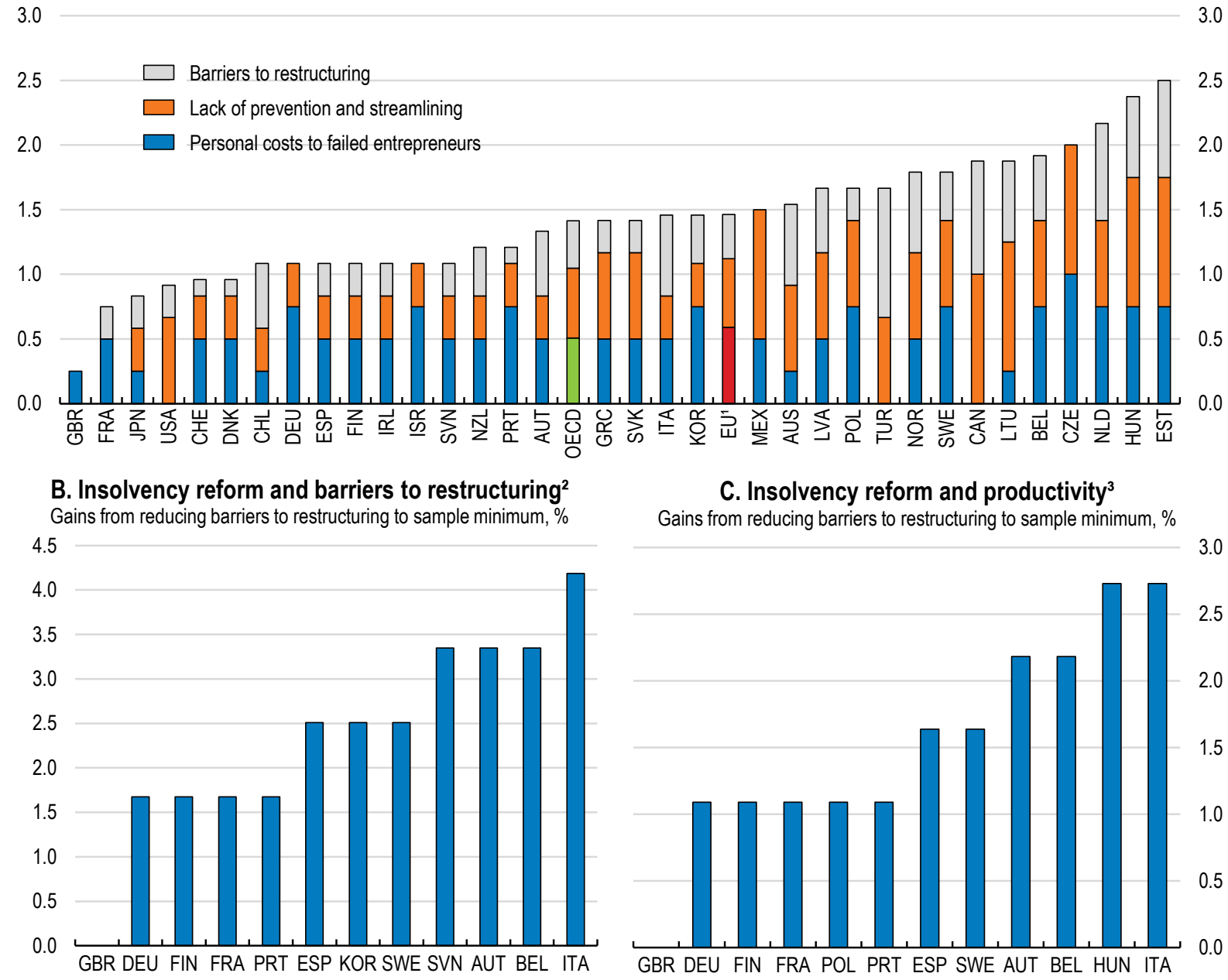

1. Simple average across the 22 countries for which data are available.

2. Potential gains to productivity-enhancing capital reallocation - the elasticity of capital growth to past firm productivity - associated with lowering the level of barriers to restructuring; percentage difference between industries with high and low exposure to insolvency regimes.

3. Potential gains to within-firm productivity growth associated with lowering the level of barriers to restructuring to sample minimum level; percentage difference between industries with high and low turnover. Source: OECD calculations based on the OECD questionnaire on insolvency regimes; Adalet McGowan, M., D. Andrews and V. Millot (2017), "Insolvency Regimes, Zombie Firms and Capital Reallocation", OECD Economics Department Working Papers, No. 1399, OECD Publishing, Paris; Adalet McGowan, M., D. Andrews and V. Millot (2017), "Insolvency Regimes, Technology Diffusion and Productivity Growth: Evidence from Firms in OECD Countries", OECD Economics Department Working Papers, No. 1425, OECD Publishing, Paris.

StatLink त्माs http://dx.doi.org/10.1787/888933741884

Taxation rues should be adjusted to remove the tax disadvantage given to equity financing relative to debt financing. A bias in favour of debt financing may lead to higher leverage, increasing bankruptcy risks and distorting allocation across firms and industries (Sorbe et al., 2017). In some countries, taxation rules also reinforce the preference of savings allocation in low-risk, short-maturity instruments. The Commission's plans in the 
2015 Action Plan on Corporate Taxation aimed at reducing the bias in the corporate tax treatment of debt and equity should be implemented, be it through carefully designed allowance for corporate equity schemes or limitations on the deduction of interest payments (OECD, 2016).

Empirical evidence suggests that the current regime of national implementation and enforcement of harmonised EU regulations leads to varying experiences of regulation and many market participants resort to country-specific legal advice in each country (Véron and Wolff, 2016). With Britain's departure from the EU approaching, relocation to financial centres in several euro area countries could result in more diverse market supervision and possibly higher cost of funding for EU firms and households.

Further efforts are needed to ensure consistent application and enforcement of European financial legislation. To this end, as recently suggested by the Commission, the European Securities Markets Agency (ESMA) could be made the direct supervisor over certain segments of national capital markets, including market entry and more central role in coordinating market abuse investigations (European Commission, 2017b). ESMA and the other European Supervisory Agencies (ESAs) could also set EU-wide priorities for supervision that would serve as a basis for the national supervisors when they draw up their respective work programmes. These proposals are welcome as they will help ensure compliance and integrate European capital markets.

At present, the ESMA has direct supervisory authority over limited market segments, namely credit rating agencies and trade repositories, and its mandate is not sufficient to foster supervisory convergence and integration of European capital markets. To ensure consistent application of the European rules, ESMA could be given direct supervisory powers in areas where national approaches tend to differ, such as the cross-border delegation decisions and supervision and resolution of central counterparties that serve international clients and hence have systemic character. In order to ensure independence and in line with international best practices, ESMA's funding should not be dependent on political negotiations about the EU budget, as is the case in the moment, but rely fully on a small levy paid by the regulated private firms to be more independent (Véron and Schoenmaker, 2017). 


\section{Recommendations on efficient stabilisation policies to strengthen euro area resilience}

\section{Reducing financial fragmentation to increase private risk-sharing}

\section{Key recommendations}

- Building on progress in risk-reduction, develop a pre-funded common European deposit insurance scheme with contributions based on risks taken by banks.

- To ensure smooth resolution of banks, use the European Stability Mechanism as a fiscally-neutral backstop for the Single Resolution Fund that can be deployed rapidly.

- Favour diversification of banks' exposure to sovereign bonds including by considering sovereign concentration charges in parallel to the introduction of a European safe asset.

- Progress in harmonising insolvency proceedings through minimum European standards allowing simpler early restructuring, shortening effective time to discharge and more efficient liquidation proceedings.

\section{Additional recommendations}

- To ensure uniform implementation and enforcement of EU capital market regulations, empower European Securities and Markets Authority to act as an effective regulator.

\section{Strengthening resilience through a common fiscal capacity}

\section{Key recommendations}

- Set up a common fiscal stabilisation capacity, for example through an unemployment benefits re-insurance scheme, and allow it to borrow in financial markets.

- Make access to the common fiscal stabilisation capacity conditional on past compliance with fiscal rules.

\section{Additional recommendations}

- Introduce more certainty into negotiated sovereign debt restructuring by reforming the European collective action clauses. 


\section{Bibliography}

Acharya, V. (2009), "Systemic risk and deposit insurance premiums", VoxEU, http://voxeu.org/article/systemic-risk-and-deposit-insurance-premiums.

Acharya, V., Santos, J. and T. Yorulmazer (2010), "Systemic risk and deposit insurance premiums", FRBNY Economic Policy Review, August.

Afonso, A. and D. Furceri (2008), "EMU enlargement, stabilisation costs and insurance mechanisms", Journal of International Money and Finance, Vol. 27, No. 2, pp. 169-187.

Allard, C. et al. (2013), "Towards a fiscal union for the euro area", IMF Staff Discussion Note SDN/13/09, International Monetary Fund, Washington, D.C.

Allen, F., Beck, T., Carletti, E., Lane P., Schoenmaker, D. and Wagner W. (2011), Cross-border banking in Europe: Implications for Financial Stability and Macroeconomic Policies, Centre for Economic Policy and Research, London.

Allen, F., Carletti, E., Goldstein, I. and Leonello, A., "Moral Hazard and Government Guarantees in the Banking Industry", Journal of Financial Regulation, 2015.

Andrews, D., M. Adalet McGowan and V. Millot (2017), "Confronting the zombies: Policies for productivity revival”, OECD Economic Policy Papers, No. 21, OECD Publishing, Paris.

Andritzky, J., Gadatsch, N., Körner, T., Schäfer, A. and I. Schnabel (2016a), "A proposal for ending the privileges for sovereign exposures in banking regulation", VoxEU, http://voxeu.org/article/endingprivileges-sovereign-exposures-banking-regulation.

Andritzky, J., Christofzik, D., Feld, L. and U. Scheuering (2016b), “A mechanism to regulate sovereign debt restructuring in the euro area", Working Paper 01/2016, German Council of Economic Experts, Wiesbaden.

Asdrubali, P., Sørensen, B. and O. Yosha (1996), "Channels of interstate risk sharing: United States 1963-1990”, Quarterly Journal of Economics, Vol. 111, No. 4, pp. 1081-1110.

Auerbach, A. and Y. Gorodnichenko (2011), "Fiscal multipliers in recession and expansion", NBER Working Paper No. 17447, National Bureau of Economic Research, Cambridge, MA.

Baldwin, R. et al. (2015), "Rebooting the Eurozone: Step I - agreeing a crisis narrative", CEPR Policy Insight No. 85, Centre for Policy Research, London.

BCBS (2017), "Discussion Paper - The regulatory treatment of sovereign exposures", Basel Committee on Banking Supervision, Basel.

BCBS (2014), "Regulatory Consistency Assessment Programme: Assessment of Basel III regulations European Union", Basel Committee on Banking Supervision, Basel.

Beblavý, M., D. Gros and I. Maselli (2015), "Reinsurance of national unemployment benefit schemes", CEPS Working Document No. 401, Centre for European Policy Studies, Brussels.

Bénassy-Quéré, A., Brunnermeier, M., Enderlein, H., Farhi, E., Fratzscher, M., Fuest, C., Gourinchas, P.O., Martin, P., Ferry, J.-P., Rey, H., Schnabel, I. Véron, N., Weder di Mauro, B. and J. Zettelmeyer (2017), "Reconciling risk sharing with market discipline: A constructive approach to euro area reform”, CEPS Policy Insight No. 91, Centre for Economic Policy Research, London.

Berger, H., Dell'Ariccia, G. and M. Obstfeld (2018), "Revisiting the economic case for fiscal union in the euro area", International Monetary Fund, Washington, D.C. 
Brůha, J., Karber, M., Pierluigi, B. and R. Setzer (2017), "Understanding sovereign rating movements in euro area countries”, ECB Working Paper No. 2011, European Central Bank, Frankfurt am Main.

Brunnermeier, M., Langfield, S., Pagano, M., Reis, R., Van Nieuwerburgh, S. and D. Vayanos (2017), "ESBies: Safety in the tranches", Economic Policy, Vol. 32, Issue 90, pp. 175-219.

Caballero, R., Farhi, E. and P.-O. Gourinchas (2017), “The safe assets shortage conundrum”, Journal of Economic Perspectives, Vol. 31, No. 3, pp. 29-46.

Cimadomo, J., Furtuna, O. and M. Guilidori (2017), "Private and public risk sharing in the euro area", Tinbergen Institute Discussion Paper 2017-064/VI, Tinbergen Institute, Amsterdam.

Claveres, G. and J. Stráský (2018), "Stabilising the euro area through an unemployment benefits reinsurance scheme", OECD Economics Department Working Paper, forthcoming.

Constâncio, V. (2017), "Synergies between banking union and capital markets union", speech at the conference on European financial integration, Brussels, 19 May 2017.

De Grauwe, P. and Y. Ji (2013), "Self-fulfilling crises in the Eurozone: An empirical test", Journal of International Money and Finance, Vol. 34, Issue 1, pp. 15-36.

Demary, M. and J. Matthes (2017), "An evaluation of sovereign-backed securities - potentials, risks and political relevance for EMU reform”, IW Policy Paper 12/2017, Institut der deutschen Wirtschaft, Cologne.

Dombret, A. (2017), "The other side of the coin - why European supervision needs international regulation", A speech delivered at the annual conference of the Banking Union, Frankfurt am Main.

Eggertsson, G. (2011), "What fiscal policy is effective at zero interest rates?", NBER Macroeconomics Annual 2010,Vol. 25, pp. 59-112.

Enria, A., Farkas, A. and L. Overby (2016), "Sovereign risk: Black swans and white elephants", European Economy: Banks, Regulation and the Real Sector, Year 2, Issue 1, pp. 51-71.

European Central Bank (2016a), "European institutional reform - establishing a European Deposit Insurance Scheme", Chapter 2 in Financial Integration in Europe, European Central Bank, Frankfurt am Main.

European Central Bank (2016b), Opinion on a proposal for a Regulation to establish a European Deposit Insurance Scheme, CON/2016/26, European Central Bank, Frankfurt am Main.

European Commission (2018a), Proposal for a Regulation on sovereign bond-backed securities, $\operatorname{COM}(2018) 339$ final, European Commission, Brussels.

European Commission (2018b), Completing the Capital Markets Union by 2019 - time to accelerate delivery, Communication from the Commission COM(2018) 114 final, European Commission, Brussels.

European Commission (2017a), On Completing the Banking Union, Communication from the Commission COM(2017) 592 final, European Commission, Brussels.

European Commission (2017b), Reinforcing integrated supervision to strengthen Capital Markets Union and financial integration in a changing environment, Communication form the Commission $\operatorname{COM(2017)} 542$ final, European Commission, Brussels.

European Commission (2017c), New budgetary instruments for a stable euro area within the Union framework, Communication from the Commission $\operatorname{COM}(2017) 822$ final.

European Commission (2015), Towards the completion of the Banking Union, Communication from the Commission $\operatorname{COM}(2015) 587$ final, European Commission, Brussels. 
European Fiscal Board (2017), Annual Report 2017, European Fiscal Board, Brussels.

European Systemic Risk Board (2018), "Sovereign bond-backed securities: a feasibility study", European Systemic Risk Board, Frankfurt am Main.

European Systemic Risk Board (2015), ESRB report on the regulatory treatment of sovereign exposures, European Systemic Risk Board, Frankfurt am Main.

Farhi, E. and I. Werning (2012), "Fiscal Unions", NBER Working Paper No. 18280, National Bureau of Economic Research, Cambridge, MA.

Frisell, L. (2016), "Europe's regulatory treatment of banks' sovereign exposures - How a flawed framework was put to use in the Irish financial crisis", European Economy: Banks, Regulation and the Real Sector, Year 2, Issue 1, pp. 105-118.

Furceri, D. and A. Zdzienicka (2015), "The euro area crisis: Need for a supranational fiscal risk sharing mechanism?”, Open Economies Review, Vol. 26, No. 4, pp. 683-710.

Gelpern, A., Heller, B. and B. Setser (2015), "Count the limbs: Designing robust aggregation clauses in sovereign bonds", Georgetown University Law Centre, Washington, D.C.

Gros, D. (2013), "Banking Union with a Sovereign Virus: The self-serving regulatory treatment of sovereign debt in the euro area", CEPS Policy Brief No. 289, Centre for European Policy Studies, Brussels.

Gros, D. and Schoenmaker, D. (2014), "European Deposit Insurance and Resolution in the Banking Union", Journal of Common Market Studies, Vol. 52, No. 3, pp. 529-546.

IMF (2014), "Strengthening the contractual framework to address collective action problems in sovereign debt restructuring", International Monetary Fund, Washington, D.C.

IMF (2010), "Uses and abuses of sovereign credit ratings", Chapter 3, Global Financial Stability Report, International Monetary Fund, Washington D.C., October.

Juncker, J.-C. et al. (2015), “Completing Europe's Economic and Monetary Union”, European Commission, Brussels.

Kiff, J., Nowak, S. and L. Schumacher (2012), "Are rating agencies powerful? An investigation into the impact and accuracy of sovereign ratings", IMF Working Paper No. 12/23, International Monetary Fund, Washington, D.C.

Lanotte, M., Manzelli, G., Rinaldi, A. M., Taboga, M. and P. Tommasino (2016), "Easier said than done? Reforming the prudential treatment of banks' sovereign exposures", Banca d'Italia Occasional Paper No. 326, Banca d'Italia, Rome.

Leandro, A. and J. Zettelmeyer (2018), “The search for a euro area safe asset”, PIIE Working Paper 18-3, Peterson Institute for International Economics, Washington, D.C.

Lenarčič, A., Mevis, D. and D. Siklós (2016), “Tackling sovereign risk in European banks”, Discussion Paper No. 1, European Stability Mechanism, Luxembourg.

MacDougall et al. (1977), Report of the Study Group on the Role of Public Finance in European Integration, European Commission, Brussels.

Milano, V. and P. Reichlin (2017), "Risk sharing across the US and EMU: The role of public institutions", VoxEU, http://voxeu.org/article/risk-sharing-across-us-and-eurozone.

Monti, M. (2010), “A new strategy for the Single Market", Report to the President of the European Commission J. M. Barroso, European Commission, Brussels. 
OECD (2016), Economic Survey of the European Union 2016, OECD Publishing, Paris.

Orphanides, A. (2017), "The fiscal-monetary policy mix in the euro area: Challenges at the zero lower bound”, Discussion Paper 60, European Commission, Brussels.

Pagano, M. (2016), "The sovereign-bank nexus and the case for European Safe Bonds", European Economy: Banks Regulation and the Real Sector, Year 2, Issue 1, pp. 129-138.

Philippon, T. and C. Hellwig (2011), "Eurobills, not Eurobonds", VoxEU, https://voxeu.org/article/eurobills-not-euro-bonds.

Praet, P. (2017), "Towards Banking Union”, A speech delivered ant the LUISS International Conference "Europe 2017: Make it or Break it", Rome.

Rachel, L. and T. D. Smith (2017), “Are low real interest rates here to stay?”, International Journal of Central Banking, Volume 13, No. 3, pp. 1-42.

Regling, K. (2018), "The role of the ESM in a deepening EMU”, speech in Ljubljana, 2 February.

Schich, S. (2008), "Financial crisis: Deposit insurance and related financial safety net aspects", Financial Market Trends, OECD Publishing Paris.

Schoenmaker, D. and Wolff, G. (2015), “Options for European deposit insurance”, VOX, CEPR's Policy Portal.

Sorbe, S., Johansson Å. and Ø. Bieltvedt Skeie (2017), "Debt and tax planning by multinationals", OECD Economics Department Working Paper No. 1357, OECD, Paris.

Sørensen, B. and O. Yosha (1998), "International risk sharing and European monetary unification", Journal of International Economics, Vol. 45, No. 2, pp. 211-238.

Strauch, R. (2018), "Euro area banks in a deepening monetary union”, speech in Frankfurt am Main, 23 February.

Ubide, M. (2015), "Stability bonds for the euro area”, PIIE Policy Brief 15-19, Peterson Institute for International Economics, Washington, D.C.

Véron, N. (2017), "Sovereign concentration charges: a new regime for banks' sovereign exposures", A paper prepared for the Economic and Monetary Affairs Committee of the European Parliament, Brussels.

Véron, N. and D. Schoenmaker (2017), "To make the best of Brexit, the European Union needs to beef up ESMA”, PIIE blog post of 21 February 2017, Peterson Institute for International Economics, Washington, D.C.

Véron, N. and G. Wolff (2016), "Capital Markets Union: A Vision for the Long Term”, Journal of Financial Regulation, Vol. 2, Issue 1, pp. 130-153.

Visco, I. (2016), "Banks' sovereign exposures and the feedback loop between banks and their sovereigns", A speech delivered at the conference "Euro50 Group: The future of European government bonds markets", Rome.

Zettelmeyer, J. (2017), "Managing deep debt crises in the euro area: Towards a feasible regime", Available at https://piie.com/system/files/documents/zettelmeyer20170525.pdf . 